OPEN ACCESS

Edited by:

Eleanor Riley,

University of Edinburgh,

United Kingdom

Reviewed by:

Amir Horowitz,

Icahn School of Medicine at

Mount Sinai, United States

Debby Burshtyn,

University of Alberta, Canada

Martin R. Goodier,

London School of Hygiene \&

Tropical Medicine, United Kingdom

*Correspondence:

Karl J. Staples

k.staples@southampton.ac.uk

Specialty section:

This article was submitted to NK and Innate

Lymphoid Cell Biology,

a section of the journal

Frontiers in Immunology

Received: 10 May 2018

Accepted: 05 July 2018

Published: 20 July 2018

Citation:

Cooper GE, Ostridge K, Khakoo SI, Wikinson TMA and Staples KJ (2018)

Human CD49a+ Lung Natural Killer

Cell Cytotoxicity in Response to

Influenza A Virus.

Front. Immunol. 9:1671.

doi: 10.3389/fimmu.2018.01671

\section{Human CD49a+ Lung Natural Killer Cell Cytotoxicity in Response to Influenza A Virus}

\author{
Grace E. Cooper ${ }^{1}$, Kristoffer Ostridge ${ }^{1,2}$, Salim I. Khakoo', Tom M. A. Wilkinson ${ }^{1,2,3}$ \\ and Karl J. Staples ${ }^{1,3 *}$
}

${ }^{1}$ Clinical and Experimental Sciences, Faculty of Medicine, Sir Henry Wellcome Laboratories, Southampton General Hospital, University of Southampton, Southampton, United Kingdom, ${ }^{2}$ Southampton NIHR Respiratory Biomedical Research Unit, Southampton General Hospital, Southampton, United Kingdom, ${ }^{3}$ Wessex Investigational Sciences Hub, Faculty of Medicine, Southampton General Hospital, University of Southampton, Southampton, United Kingdom

Influenza A virus (IAV) is a major global public health burden due to its routine evasion of immunization strategies. Natural killer (NK) cells are innate cytotoxic cells with important antiviral activity in the human body, yet the function of these cells in the control of IAV infection is unclear. The aim of this study was to determine the role of lung NK cell cytotoxic responses to IAV. Human lung explants were infected ex vivo with IAV, and lung NK cell activation was analyzed by flow cytometry. Cytotoxic responses of NK cell subsets against IAV-infected macrophages were measured by flow cytometry and ELISA. Despite reports of hypofunctionality in the pulmonary environment, human lung-associated NK cells responded rapidly to ex vivo IAV infection, with upregulation of surface CD107a $24 \mathrm{~h}$ post-infection. The lung NK cell phenotype is similar in maturity and differentiation to NK cells of the peripheral blood but a unique $\mathrm{CD}^{6}{ }^{\text {bright }} \mathrm{CD} 49 \mathrm{a}^{+} \mathrm{CD} 103^{+} \mathrm{CD} 69^{+} \mathrm{NK}$ cell population was identified in the lung, indicating NK cell residency within this organ. In response to ex vivo IAV infection a greater proportion of resident CD56 bright CD49a+ NK cells expressed surface CD107a compared with CD56 bright $C D 49 a^{-}$NK cells, suggesting a hyperfunctional NK cell population may be present within human lung tissue and could be the result of innate immunological training. Furthermore, NK cells provided significant antiviral, cytotoxic activity following contact with influenza-infected cells, including the production and release of IFN- $\gamma$ and granzyme-B resulting in macrophage cell death. These results suggest that a resident, trained NK cell population are present in the human lung and may provide early and important control of viral infection. A greater understanding of this resident mucosal population may provide further insight into the role of these cells in controlling viral infection and generating appropriate adaptive immunity to IAV.

Keywords: natural killer cells, human lung, viral infection, cytotoxicity, CD49a

\footnotetext{
Abbreviations: APC, antigen-presenting cell; COPD, chronic obstructive pulmonary disease; CR-PB, peripheral blood from cancer resection donor; E:T, effector:target; GzmB, granzyme-B; H-PB, healthy peripheral blood; IAV, influenza A virus; ILC, innate lymphoid cell; IQR, interquartile range; MACS, magnetic-activated cell sorting; MDM, monocyte-derived macrophage; MOI, multiplicity of infection; NCR, natural cytotoxicity receptor; NTHi, non-typeable Haemophilus influenzae; NP1, nucleoprotein-1; PBMCs, peripheral blood mononuclear cells; PMA/I, phorbol myristate acetate/ionomycin; SMFI, specific mean fluorescence intensity; ssRNA, single-stranded ribonucleic acid; TCR, T cell receptor.
} 


\section{INTRODUCTION}

Influenza A virus (IAV) is a single-stranded ribonucleic acid virus of the Orthomyxoviridae family causing acute infection of the upper and lower respiratory tract (1). IAV infection remains a global public health burden with 3-5 million cases of severe illness and 500,000 deaths worldwide, annually (2). Vaccination is currently the best method of controlling viral transmission; however, annual influenza vaccines are limited in efficacy due to rapid viral evolution, time required for production and ineffectiveness in high-risk groups $(3,4)$. Improving the current immunization strategies requires a more advanced understanding of both innate and adaptive human immunity to influenza virus (5).

The lungs are one of the largest reservoirs of natural killer (NK) cells in the body, yet the function of these cells in pulmonary viral infection is poorly understood $(6,7)$. NK cells are antiviral lymphocytes essential to the control of human pathogens such as hepatitis $\mathrm{C}$ virus, cytomegalovirus, and human immunodeficiency virus $(8,9)$. NK cells aid viral clearance through secretion of pro-inflammatory cytokines such as IFN- $\gamma$ as well as cytotoxic granules and engagement of death receptors, which stimulate target cell apoptosis (8). Different subpopulations of human NK cells can be identified through high and low expression of CD56, and these populations of NK cells have been ascribed different functions. CD56 $6^{\text {bright }}$ NK cells are thought to be predominantly cytokine producing while CD56 ${ }^{\mathrm{dim}}$ NK cells represent the canonical cytotoxic NK cell; however, these functional outputs appear dependent on the type of in vitro stimulation and the role of these NK cell subtypes within the human body remain largely unexplored (10-14).

Natural killer cells recognize virally infected cells through the integration of signaling from activatory and inhibitory germline encoded receptors on the NK cell surface (15). In vitro binding studies have shown that the activatory NK cell receptors NKG2D and NKp46, and inhibitory KIR2DL2 NK cell receptor bind influenza-infected cells (16-18). Furthermore, strong IFN- $\gamma$ responses are observed in the NK cells of the peripheral blood following influenza vaccination (19-22). The majority of mouse models of influenza infection implicate a protective role for NK cells during infection (23-27). Indeed $\mathrm{Ncr}^{-1-}$ (NKp46) knockout in the mouse results in lethal influenza infection (24). However, in most high dose infection models, murine NK cells appear to play a detrimental role, contributing to influenza pathogenesis $(28,29)$. This may suggest there is a delicate balance between protective and destructive NK cell activation during IAV infection. But due to differences in influenza strain, dose, and genetic background of the mice, it is difficult to delineate what role NK cells may play in murine models of influenza infection.

The majority of studies investigating the human NK cell responses to influenza utilize peripheral blood NK cells $(17,19-22)$. However, organ-resident NK cell populations have recently been identified in the liver, uterus, and secondary lymphoid tissue, with resident populations expressing CD103, CD69, and CD49a (30-34). Phenotypically different from the blood, these populations have been linked to NK cell memory and may possess different functionality as a result of "training" by their environment (35). Lung NK cell residency has been disputed, with lung NK cells often described as hypofunctional (36-39). However, there is some evidence that NK cell memory can be generated to respiratory virus, as murine influenza infection induced liver $\mathrm{CD} 49 \mathrm{a}^{+} \mathrm{NK}$ cells that are protective against influenza infection (40). Furthermore, influenza vaccination results in a more potent $\mathrm{NK}$ cell response to influenza in human peripheral blood mononuclear cells (PBMCs) (41).

The contribution of NK cells to pulmonary health and disease is poorly understood in humans and how NK cells may respond to influenza infection has not been characterized in a model effectively recapitulating human infection. The aim of this study was therefore to investigate the role of human lung NK cells in early influenza control using our previously characterized lung explant model of influenza infection (42-44).

\section{MATERIALS AND METHODS}

\section{Volunteer Recruitment}

Lung tissue distal from tumor sites and peripheral blood was obtained from lobectomy patients. Blood was also obtained from healthy human volunteers. All studies were approved by Southampton and South West Hampshire Research Ethics Committees (13/SC/0416 for healthy control group, 09/H0504/109 for resection and blood donors, and 15/SC/0528 for age comparison). All participants provided written informed consent.

\section{Preparation of Lung Tissue and Explant Infection}

Lung tissue explants were prepared as previously described and infected with X31 (H3N2) IAV (Virapur) as previously described $(43,44)$. Briefly, lung tissue explants were cut into 4-6 $\mathrm{mm}^{2}$ pieces with 6 fragments/well and washed thoroughly with cold RPMI. The lung explants were then rested for $16 \mathrm{~h}$ in complete RPMI [RPMI with $10 \% \mathrm{FCS}, 2 \mathrm{mg} / \mathrm{mL}$ L-glutamine, $0.05 \mathrm{IU} / \mathrm{mL}$ penicillin, $50 \mu \mathrm{g} / \mathrm{mL}$ streptomycin, and $0.25 \mu \mathrm{g} / \mathrm{mL}$ amphotericin B (Sigma)] to remove contaminant blood. For NK cell phenotyping, the lung tissue was digested in $0.5 \mathrm{mg} / \mathrm{mL}$ collagenase, filtered through a $0.7-\mu \mathrm{m}$ filter, and mononuclear cells isolated by density gradient centrifugation over a Ficollpaque layer. Cells isolated from the buffy coat were then stained for flow cytometry. For IAV infection of lung explants, lung fragments were washed in PBS and infected with 200,000 pfu/mL live or UV-irradiated X31 (H3N2) IAV (Virapur) following rest $(42,45)$. UV-irradiated X31 was created by exposing live X31 to UV light for $2 \mathrm{~h}$ on ice. $2 \mathrm{hpi}$ extracellular virus was removed by washing in PBS and explants cultured in fresh media for a further $22 \mathrm{~h}$, or for stated time point. X31 replication was detected through intracellular viral nucleoprotein-1 (NP1) expression. In addition, lung explants were alternatively treated with phorbol myristate acetate/ionomycin (PMA/I-1.34 $\mu \mathrm{M}$ and $81 \mathrm{nM}$, respectively). After infection NK cells were dispersed from tissue using $0.5 \mathrm{mg} / \mathrm{mL}$ collagenase, the digest filtered and cells stained for flow cytometry.

A median of $410,676 \pm 153,226 \mathrm{CD}^{4} 5^{+}$leukocytes were isolated per resection sample, according to flow cytometry analysis. The median total events in the NK cell gate was 10,011 $\pm 9,073$ 
and a minimum value of $2,760(N=8)$. For the rarer CD56 bright CD $49 \mathrm{a}^{+} \mathrm{NK}$ cells, the median number of events was $940 \pm 194$ and a minimum value of 130; a cutoff of a minimum 100 events in this gate was required to be included in the analysis $(N=8)$. The same cutoff was used in the functional studies of the $\mathrm{CD} 56^{\text {bright }} \mathrm{CD} 49 \mathrm{a}^{+}$ population. The median number of events for CD56 ${ }^{\text {bright }} \mathrm{CD} 49 \mathrm{a}^{+}$ NK cells in the X31-infected explant was 1,035 \pm and a minimum value of $164(N=5)$. This was also typical of the untreated and UV-irradiated X31 treated explant tissue.

\section{Blood NK Cell and Monocyte Isolation and Differentiation}

Human PBMCs were isolated from heparinized blood of healthy volunteers or from cancer resection donors. Blood was diluted 1:1 with PBS and mononuclear cells isolated by density gradient centrifugation on Ficoll-Paque (GE Healthcare). Monocytes were isolated from PBMC by CD14-positive magnetic-activated cell sorting (MACS) (Miltenyi Biotec). Monocytes were seeded at 500,000 cells/well $\left(1 \times 10^{6}\right.$ cells $\left./ \mathrm{ml}\right)$ and differentiated into monocyte-derived macrophages (MDMs) over 12 days in complete RMPI with $2 \mathrm{ng} / \mathrm{mL}$ GM-CSF, as described previously (46). Autologous NK cells were isolated from the CD14-depleted MACS filtrate by negative selection with an NK cell isolation kit (Miltenyi) according to the manufacturer's instructions. Purified NK cells $\left(94.28 \% \mathrm{CD}^{-} \mathrm{CD}^{2} 6^{+}, \mathrm{N}=5\right)$ were frozen in FCS containing 10\% DMSO (Sigma) until use.

\section{Macrophage Infection and Co-Culture With NK Cells}

Monocyte-derived macrophage infection was performed as previously described (43). MDMs were treated with $500 \mathrm{pfu} / \mathrm{mL}$ of live or UV-irradiated X31 virus for $2 \mathrm{~h}$, before removal of extracellular virus by washing with $\mathrm{PBS}$ and incubation for a further $22 \mathrm{~h}$. UV-irradiated X31 was created by exposing live X31 to UV light for $2 \mathrm{~h}$ on ice. After $24 \mathrm{~h}$, autologous NK cells were thawed and cultured with untreated or infected MDMs for $6 \mathrm{~h}$ at an effector:target (E:T) of 1:5. This E:T was chosen following testing of a range of E:T of NK cells to X31-infected MDMs, as shown in Figure S1 in Supplementary Material and was chosen for the optimal detection of NK cell IFN- $\gamma$ production. NK cell degranulation, IFN- $\gamma$ and GzmB production and MDM viability were measured by flow cytometry. Adherent MDMs were collected for flow cytometry with non-enzymatic cell dissociation solution (Sigma). To measure the accumulation of intracellular molecules $2 \mu \mathrm{M}$ Monensin (eBiosciences) was added into the co-culture $1 \mathrm{~h}$ after the addition of NK cells. Physical contact between MDMs and NK cells was prevented through culturing in a transwell system with NK cells in the top compartment (Costar). HLA class I binding was blocked through incubation of $20 \mu \mathrm{g} / \mathrm{mL} \alpha \mathrm{HLA}-\mathrm{A} / \mathrm{B} / \mathrm{C}$ (W6/32; BioLegend) with MDM $20 \mathrm{~min}$ prior to addition of NK cells.

\section{Flow Cytometry}

Flow cytometry was performed as previously described, all steps were performed at $4^{\circ} \mathrm{C}$ for $30 \mathrm{~min}$, unless otherwise stated (43). Cell viability was assessed by staining with Zombie Violet Fixable
Viability Kit (BioLegend) in PBS. Surface marker staining was performed in $2 \mathrm{mM}$ EDTA and $0.5 \%$ bovine serum albumin (FACS buffer) with $2 \mathrm{mg} / \mathrm{mL}$ human IgG (Sigma). Cellular surface markers were stained with the following antibodies; $5 \mu \mathrm{L}$ $\alpha \mathrm{CD} 3$-PerCP (UCHT1), $5 \mu \mathrm{L} \alpha \mathrm{CD} 56-\mathrm{PECy} 7$ (HCD56), $5 \mu \mathrm{L}$ $\alpha$ CD57-PacificBlue (HCD57), $5 \mu \mathrm{L} \alpha \mathrm{CD} 103-\mathrm{APC}$ (Ber-ACT8), $5 \mu \mathrm{L} \alpha \mathrm{CD} 69-\mathrm{BV} 421$ (FN50), $5 \mu \mathrm{L} \alpha \mathrm{CD} 107 \mathrm{a}-\mathrm{BV} 510$ (H4A3) (BioLegend), $5 \mu \mathrm{L} \alpha \mathrm{CD} 45-\mathrm{BV} 510$ (HI30), $5 \mu \mathrm{L} \alpha \mathrm{CD} 16-\mathrm{FITC}$ (3G8), $20 \mu \mathrm{L} \alpha \mathrm{CD} 49 \mathrm{a}-\mathrm{PE}$ (SR84), $20 \mu \mathrm{L} \alpha \mathrm{CD} 158 \mathrm{~b}-\mathrm{PE}(\mathrm{CH}-\mathrm{L}$ ) (BD Biosciences) and with corresponding isotype controls; Mouse IgG1-PerCP, IgG1-PECy7, IgG2b-PE, IgM-Pacific Blue, IgG1-APC, IgG1-BV421 (BioLegend) Mouse IgG1-BV510, IgG1FITC, IgG1-PE (BD Biosciences). Macrophages and epithelia were stained with, $5 \mu \mathrm{L} \alpha \mathrm{HLA}-\mathrm{DR}-\mathrm{APC}-\mathrm{Cy} 7$ (L243) and $20 \mu \mathrm{L}$ $\alpha$ EpCAM-PerCP-Cy5.5 (EBA-1), $5 \mu \mathrm{L} \alpha \mathrm{HLA}-\mathrm{ABC}-\mathrm{PE}(\mathrm{W} 6 / 32)$ (BD Biosciences). Corresponding isotype controls not previously stated included mouse IgG2a-APC-Cy7 (BD Biosciences) and IgG2a-PE (Life Tech). Cells were then fixed and permeabilized with Cytofix/Cytoperm (BD Biosciences, Oxford, UK) for $20 \mathrm{~min}$ before intracellular staining. Intracellular staining was performed in $1 \times$ Permwash (BD Biosciences) in FACS staining buffer. Intracellular markers were assessed with $2 \mu \mathrm{L} \alpha-\mathrm{NP}-1$ FITC (ab20921) (Abcam), $5 \mu \mathrm{L} \alpha$ IFN- $\gamma$-PerCP-Cy5.5 (4S.B3), or $5 \mu \mathrm{L} \alpha \mathrm{Gzm}-\mathrm{B}-\mathrm{APC}$ (QA16A02) (BioLegend). Flow cytometric analysis was performed on a FACSAria using FACSDiva software v5.0.3 (BD Biosciences) and FlowJo v10 (Tree Star). The t-SNE algorithm was applied within FlowJo v10 for 1,000 iterations to produce $2 \mathrm{D}$ projections of the data using a perplexity value of 20 . FCS files from the lung and matched blood, or lung only, were downsampled to 300 or 600 cells, respectively.

\section{ELISA}

IFN- $\gamma$ ELISA MAX (BioLegend), and Granzyme B duoset ELISA (R\&D Systems) were all carried out according to the manufacturer's protocol.

\section{Statistics}

Statistical analyses were performed using either a Chi-squared test, Fisher's test, Wilcoxon's matched-pairs signed-rank test, Mann-Whitney $U$ test, Kruskal-Wallis or Friedman test with Dunn's multiple comparison testing as appropriate (GraphPad Prism v7.0, GraphPad Software Inc., San Diego, CA, USA). Data are expressed as medians. Results were considered significant if $P<0.05$.

\section{RESULTS}

\section{NK Cells Are Present at High Frequencies in Human Lung Parenchyma}

Natural killer cells were isolated from human lung parenchyma, matched peripheral blood and peripheral blood from healthy controls. NK cells were defined as $\mathrm{CD} 45^{+} \mathrm{CD} 3{ }^{-} \mathrm{CD} 56^{+}$cells by flow cytometry and made up a median of $18.55 \pm 14.98 \%$ of $\mathrm{CD} 45^{+}$lymphocytes isolated from the human lung parenchyma $\left(N=17\right.$, Figure 1). CD $56^{\text {bright }} \mathrm{CD} 16^{-}, \mathrm{CD} 56^{\mathrm{dim}} \mathrm{CD} 16^{+}$, and $\mathrm{CD} 56^{\mathrm{dim}} \mathrm{CD} 16^{-} \mathrm{NK}$ cells were all identified in lung and blood with 


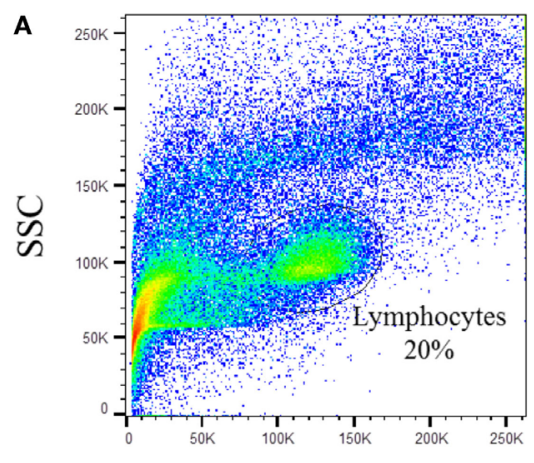

FSC-A

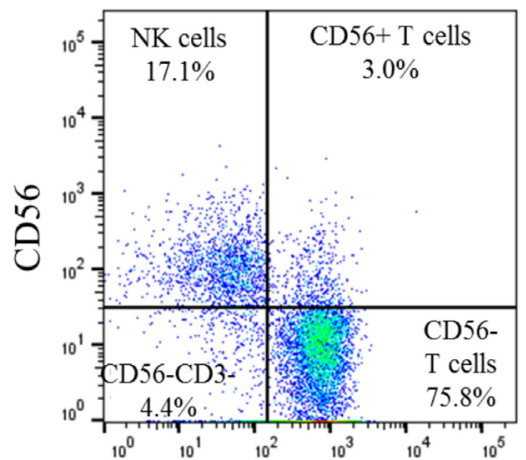

CD3

B

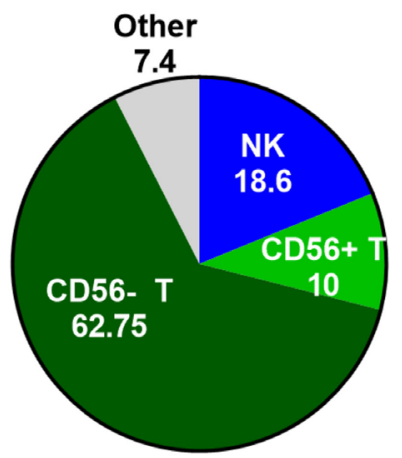

D

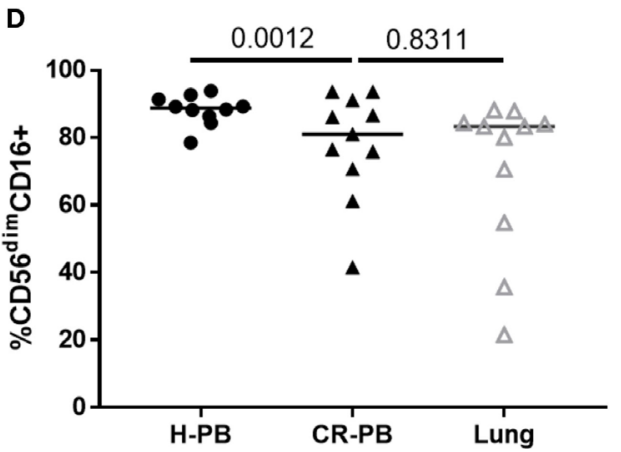

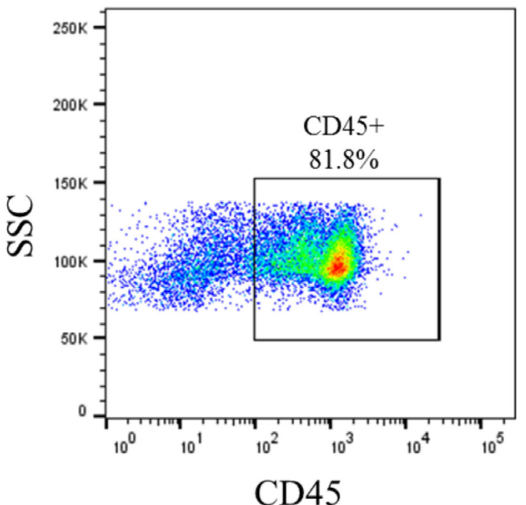

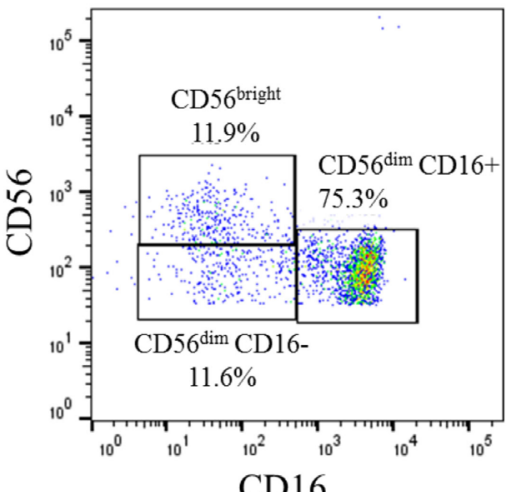

C

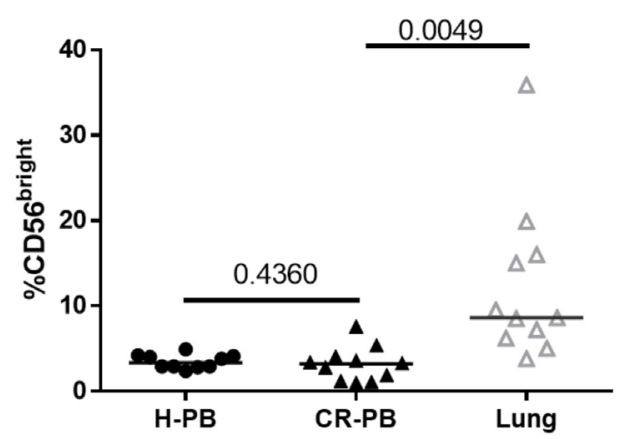

E

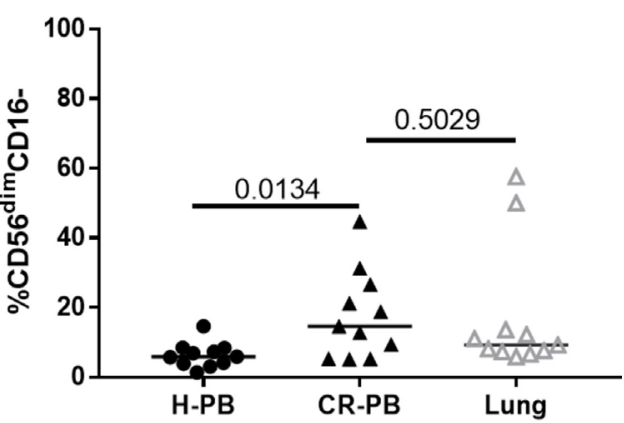

FIGURE 1 | Lung-associated natural killer (NK) cells are highly differentiated and similar to the peripheral blood of healthy donors [healthy peripheral blood ( $\mathrm{H}-\mathrm{PB})$ ] and those undergoing cancer resection [peripheral blood from cancer resection donor (CR-PB)]. (A) Representative gating strategy to define NK cells and NK cell subpopulations isolated from human lung parenchyma. (B) Quantification of lung CD45+ lymphocytes, $N=23$. (C-E) Proportions of CD56 bright, CD56 dim CD16 ${ }^{+}$, and CD56 ${ }^{\text {dim } C D 16-~ N K ~ c e l l s ~ i n ~ H-P B ~}(N=14)$, lung tissue $(N=23)$, and matched blood $(C R-P B, N=23)$. 
CD56 ${ }^{\mathrm{dim}} \mathrm{CD} 16^{+}$and $\mathrm{CD} 56^{\mathrm{dim}} \mathrm{CD} 16^{-}$found in similar proportions between the lungs and peripheral blood $(P=0.83$ and $P=0.50$, Figures 1C-E). As described by Marquardt et al., the majority of lung-associated NK cells are canonical cytotoxic CD56 ${ }^{\mathrm{dim}} \mathrm{CD} 16^{+}$ cells (39). However, we observed an increased proportion of CD56 ${ }^{\text {bright }} \mathrm{NK}$ cells in the lungs compared with matched peripheral blood (8.6 vs 3.3\%, $P=0.0049$, Figure 1C). Furthermore, fewer $\mathrm{CD} 56^{\mathrm{dim}} \mathrm{CD} 16^{+} \mathrm{NK}$ cells $(P=0.0012)$ and a greater proportion of $\mathrm{CD} 56^{\mathrm{dim}} \mathrm{CD} 16^{-} \mathrm{NK}$ cells were isolated from the blood of cancer resection patients compared with healthy control blood.

These differences in the NK cell subpopulations may reflect differences in the cohort age and smoking status between healthy controls and donors undergoing resection surgery, as shown in Table 1. To assess the effect of age on NK cell subpopulations of the blood, the proportions of CD56 $6^{\text {bright }}$ and CD56 ${ }^{\text {dim }}$ NK cells were analyzed from the blood of healthy controls aged above and below 40 (donor demographics shown in Table 2). However, no differences were observed in the peripheral NK cell subpopulations of these two cohorts (Figure 2).

TABLE 1 | Cohort demographics for resection donors and healthy controls.

\begin{tabular}{lccc}
\hline & $\begin{array}{c}\text { Cancer } \\
\text { resection } \\
\text { donors }\end{array}$ & $\begin{array}{c}\text { Healthy } \\
\text { control donors } \\
\text { (phenotyping) }\end{array}$ & P-value \\
\hline Number of patients & 35 & 15 & \\
Age (years) & $70(9.75)$ & $24(8)$ & $<0.0001^{\text {b }}$ \\
M/F & $21 / 14$ & $10 / 5$ & $0.7570^{c}$ \\
Smoking status, never/ & $5 / 22 / 7 / 1$ & $10 / 4 / 1$ & $0.0013^{\text {d }}$ \\
ex/current/unknown & & $\mathrm{NA}$ & $\mathrm{NA}$ \\
Pack-years of smoking & $40(33.75)$ & $\mathrm{NA}$ & $\mathrm{NA}$ \\
FEV1\% & $86(28.5)$ & $\mathrm{NA}$ & $\mathrm{NA}$ \\
FEV1/FVC ratio & $0.65(0.15)$ & $\mathrm{NA}$ & \\
Resection location, LUL/ & $8 / 7 / 11 / 3 / 3$ & & \\
LLL/RUL/RML/RLL & $1 \mathrm{RUL}+\mathrm{LUL}^{\mathrm{a}}$ & & \\
& $1 \mathrm{RUL}+\mathrm{RML}^{\mathrm{a}}$ & & \\
& 1 Left & & \\
& pneumonectomy & &
\end{tabular}

Median values and italicized interquartile range are shown.

NA, data not available.

${ }^{a}$ Additional locations of resection surgeries.

${ }^{b}$ Two-tailed Mann-Whitney test.

cFisher's test.

${ }^{d}$ Chi-square test.

TABLE 2 | Cohort demographics for age comparison study.

\begin{tabular}{lccc}
\hline & $\begin{array}{c}\text { Healthy control } \\
\text { (under 40) }\end{array}$ & $\begin{array}{c}\text { Healthy control } \\
\text { (over 40) }\end{array}$ & P-value \\
\hline Number of patients & 10 & 12 & \\
Age (years) & $34(5.5)$ & $66.5(7)$ & $<0.0001^{\mathrm{a}}$ \\
M/F & $4 / 6$ & $4 / 8$ & $0.5315^{\mathrm{b}}$ \\
Smoking status, & $6 / 3 / 1$ & $6 / 6 / 0$ & $0.3998^{\mathrm{c}}$ \\
never/ex/current & & & \\
Pack-years of smoking & $0(1.605)$ & $2(20)$ & $0.2332^{\mathrm{a}}$ \\
FEV1\% & $97(17.75)$ & $108(16.5)$ & $0.0143^{\mathrm{a}}$ \\
FEV1/FVC ratio & $0.84(8.5)$ & $0.78(2.75)$ & $0.1945^{\mathrm{a}}$ \\
\hline
\end{tabular}

Median values and italicized interquartile range are shown.

aTwo-tailed Mann-Whitney test.

${ }^{b}$ Fisher's test.

${ }^{c}$ Chi-squared test.
To evaluate the maturity of lung NK cells, the expression of CD57 and CD158b (KIR2DL2/L3/S2) was analyzed on lung and blood NK cells. CD57 is expressed in the late stages of NK cell differentiation and is associated with increased NK cell functionality $(47,48)$. KIR expression also increases during NK cell maturation, as NK cells gain cytotoxic function $(49,50)$. Although CD158b does not evaluate the expression of all KIR, which vary across individuals, it represents KIR from both haplotypes A and B (51). Individuals with haplotype A typically possess KIR alleles with a more inhibitory role than the KIR haplotype $B$, which has a more activating effect on NK cell function (52). Both CD57 and CD158b were expressed equivalently between lung and matched peripheral blood (Figures 3A,C, $P=0.91$ and $P=0.07$, respectively). Furthermore, no significant differences were observed in the expression of either CD57 or CD158b on CD56 $6^{\text {bright }}$ or CD $56^{\text {dim }}$ NK cell subpopulations (Figures 3B,D). To investigate whether the differentiation state of CD158b-positive and -negative NK cells were different between matched blood and lung, the co-expression of CD57 and CD158b was analyzed, as shown in Figures 3E,F; however, no significant differences were observed $[P>0.9999$ for each analysis of $\mathrm{CD}^{2} 7^{+} \mathrm{CD} 158 \mathrm{~b}^{-}, \mathrm{CD}^{2} 7^{-} \mathrm{CD} 158 \mathrm{~b}^{+}$, double-positive (DP), and double-negative NK cells]. In addition, NKG2C, an activating receptor associated with CMV immunity and memory response was not found to be differentially expressed between blood and lung (Figures 3G,H) $(53,54)$. Thus, lung NK cells appear to mirror the phenotype of the peripheral blood, as highly mature and terminally differentiated NK cells. These results confirm reports by Marquardt et al. and other studies from the human lung $(39,55)$.

\section{Distinct CD49a ${ }^{+}$CD103 ${ }^{+}$CD69 ${ }^{+}$NK Cell Populations Are Present in the Lung Parenchyma}

Natural killer cells isolated from the lungs and peripheral blood appear phenotypically similar in terms of their CD16, CD57, CD158b, and NKG2C expression (Figures 1 and 3); however, a distinct $\mathrm{CD} 49 \mathrm{a}^{+} \mathrm{NK}$ cell population was identified from the lung parenchyma, which was not found in the circulation (Figure 4). CD $49 \mathrm{a}^{+}$NK cells made up $13.3 \pm 11 \%$ of the total lung-associated $\mathrm{NK}$ cell population and were primarily CD56 ${ }^{\text {bright }} \mathrm{CD} 16^{-}$and $\mathrm{CD} 56^{\mathrm{dim}} \mathrm{CD} 16^{-} \mathrm{NK}$ cells (42.2 and $27.3 \%$, respectively, Figures 4A,B). Negligible amounts of CD49a were detected on $\mathrm{CD} 56^{\mathrm{dim}} \mathrm{CD} 16^{+} \mathrm{NK}$ cells. Other putative markers of residency including CD69 and CD103 were also identified in the lung parenchyma with $3.65 \pm 7.65 \%$ of lung NK cells expressing $\mathrm{CD}_{103}{ }^{+}$, a marker also not found in the blood $(P=0.016$, Figures 4C,D). The expression of CD103 mirrored that of CD49a, with most CD103 expressed on $\mathrm{CD} 56^{\text {bright }}$ and $\mathrm{CD} 56^{\mathrm{dim}} \mathrm{CD} 16^{-}$ NK cells. Although CD69 was not expressed differently between blood and lung at the whole NK cell level $(P=0.85), \mathrm{CD} 56^{\text {bright }}$ lung NK cells expressed greater levels of CD69 compared with the blood $(P=0.0015$, Figures 4E,F). CD69 was expressed at similar levels by lung CD56 ${ }^{\mathrm{dim}} \mathrm{CD} 16^{+}$and CD $56^{\text {dim }} \mathrm{CD} 16^{-} \mathrm{NK}$ cells $(P=0.33$ and 0.18$)$. 

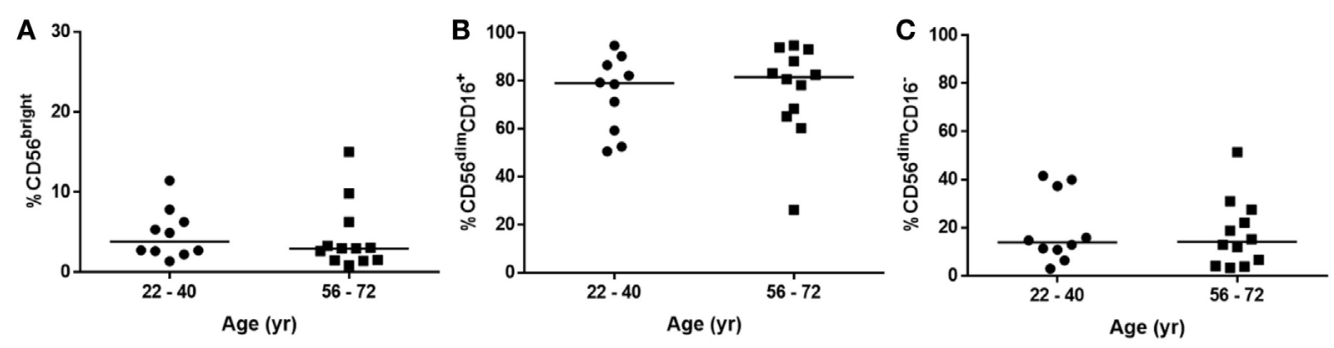

FIGURE 2 | Natural killer cell subpopulation proportions are not affected by age. (A) CD56 $6^{\text {bight }}$, (B) CD56 ${ }^{\text {dim }} C D 16^{+}$, and (C) CD56 $6^{\text {dim }}$ CD16 ${ }^{-}$proportions in peripheral blood of healthy donors aged 22-40 $(N=10)$ and $56-72(N=12)$. Statistical analysis by Mann-Whitney $U$ test, lines describe medians.

The co-expression of CD49a, CD69, and CD103 on lung and blood CD56 ${ }^{\text {bright }}$ NK cells was analyzed as shown in Figures 5A,B and visualized in t-SNE plots (Figures 5C,D). Lung CD56 $6^{\text {bright }}$ NK cells clustered together and appeared distinct to CD56 $6^{\text {bright }}$ of matched peripheral blood (Figure 5C). Analysis of CD49a, CD69, and CD103 expression on lung NK cells suggests that the CD56 $6^{\text {bright }}$ population consists of $\mathrm{NK}$ cells that are single-positive (SP), DP, and triple-positive for these markers (Figures 6D,F). Whereas only CD69 could be identified in the peripheral blood CD56 ${ }^{\text {bright }}$ population (Figures $5 \mathbf{B}, \mathbf{G}$ and $4 \mathrm{E})$. SP CD49a $\mathrm{a}^{+} \mathrm{NK}$ cells were positioned together with triple- and DP populations within the t-SNE analysis; however, CD56 ${ }^{\text {bright }}$ NK cells that were SP for CD69 appeared more distinct, as did NK cells negative for all tested residency markers (Figure 5D). CD69 and CD103 were both strongly co-expressed on $\mathrm{CD} 56^{\text {bright }} \mathrm{CD} 49 \mathrm{a}^{+} \mathrm{NK}$ cells, indicating that this population may be resident within the lungs (Figure 5E). One of the largest populations of lung CD56 $6^{\text {bright }} \mathrm{NK}$ cells were $\mathrm{CD} 49 \mathrm{a}^{+} \mathrm{CD}_{69}{ }^{+} \mathrm{CD} 103^{+}$, which made up $20.9 \pm 12.66 \%$ of the CD56 $6^{\text {bright }}$ lung NK cell population (Figures 5E,F).

\section{Ex Vivo IAV (H3N2) Infects the Macrophages and Epithelia of Human Lung Explants}

Natural killer cells make up a substantial proportion of the lung $\mathrm{CD}_{4} 5^{+}$leukocytes $(18.55 \pm 14.98 \%)$ and their response to respiratory infection may have important implications for human disease. Furthermore, lung-resident NK cell populations such as the CD49a $\mathrm{a}^{+} \mathrm{NK}$ cells may be shaped by insult and homeostasis within the lung microenvironment. Therefore, to understand the functional relevance of the lung NK cell phenotypes described here, the response of lung NK cells to IAV infection was characterized in human lung parenchyma. The lung explants were infected with 200,000 pfu/mL UV-irradiated or live X31 IAV for $2 \mathrm{~h}$ before removal of extracellular virus and further culture for a further $22 \mathrm{~h}$. Cells were defined as infected when viral NP1 was detected (Figures 6A,B). UV-irradiated IAV was not found to replicate within the lung tissue, as determined by NP1 expression, indicating that the virus is no longer viable (Figures $\mathbf{6 C , F}$ ). In this model, $7.07 \%$ of lung epithelia (defined as $\mathrm{CD}^{4} 5^{-} \mathrm{EpCAM}^{+}$cells, Figures $\mathbf{6 A}, \mathbf{B}$ ) and $22.3 \%$ of macrophages (defined as CD $45^{+} \mathrm{HLA}-\mathrm{DR}^{+}$cells, Figures 6D,E) were infected with IAV. Both the airway epithelium and macrophages increased expression of cell surface HLA class I, a key molecule controlling NK cell activation, in response to infection (epithelium $P=0.0078$, macrophage $P=0.0020$, Figures 6G-H).

\section{NK Cells Activate in Response to Influenza Infection of Human Lung Explant}

Natural killer cells were strongly activated $24 \mathrm{~h}$ post influenza infection (hpi), with a twofold increase in surface CD107a when compared with UV-irradiated X31 treated explant (Figures 7B, $P=0.047$ ). NK cell degranulation was not dominated by any particular subpopulation as CD56 $6^{\text {bright }}$, $\mathrm{CD}^{2} 6^{\mathrm{dim}} \mathrm{CD} 16^{+}$, and $\mathrm{CD} 56^{\mathrm{dim}} \mathrm{CD} 16^{-} \mathrm{NK}$ cells all expressed similar levels of CD107a in X31-infected tissue (Figure 5C). There was a slight trend toward increased NK cell degranulation when MDMs were exposed to UV-irradiated virus compared with uninfected (NT) controls $(P=0.094$, Figure 7B). Since multiple influenza infections may be experienced throughout life, we hypothesized that prior exposure to influenza may have resulted in increased functionality of the lung CD $49 \mathrm{a}^{+} \mathrm{NK}$ cell populations (Figure 4). To investigate this, the degranulation of $\mathrm{CD} 56^{\text {bright }} \mathrm{CD} 49 \mathrm{a}^{+} \mathrm{NK}$ cells in response to $\mathrm{X} 31$ infection was compared with $\mathrm{CD} 56^{\text {bright }} \mathrm{CD} 49 \mathrm{a}^{-} \mathrm{NK}$ cells. As shown in Figure 7D, the degranulation of $\mathrm{CD} 56^{\text {bright }} \mathrm{CD} 49 \mathrm{a}^{+} \mathrm{NK}$ cells was increased relative to $\mathrm{CD} 56^{\text {bright }} \mathrm{CD} 49 \mathrm{a}^{-} \mathrm{NK}$ cells $(12.2$ vs $19.2 \%, P=0.031) 24 \mathrm{hpi}$, indicating that these NK cells may be more responsive to influenza infection. Furthermore, CD56 ${ }^{\text {bright }} \mathrm{CD} 49 \mathrm{a}^{+}$and CD $49 \mathrm{a}^{-} \mathrm{NK}$ cells were not differentially activated when explants were treated with PMA/I, indicating that the total potential of $\mathrm{CD} 56^{\text {bright }} \mathrm{CD} 49 \mathrm{a}^{+} \mathrm{NK}$ cells is similar to $\mathrm{CD} 56^{\text {bright }} \mathrm{CD} 49 \mathrm{a}^{-} \mathrm{NK}$ cells. Thus, this may be a virus-specific

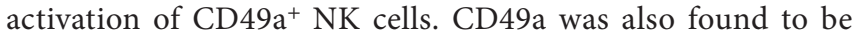
expressed on $\mathrm{CD} 56^{\mathrm{dim}} \mathrm{CD} 16^{-} \mathrm{NK}$ cells; however, no difference in the response to virus was observed between $\mathrm{CD} 56^{\mathrm{dim}} \mathrm{CD} 16^{-}$ CD49a ${ }^{+}$and CD49a- NK cells (Figure 7E).

Increased CD107a on the NK cells surface was mirrored by increased release of granzyme-B (GzmB) and IFN- $\gamma$ (Figures 7F,G, $P=0.0078$ and $P=0.0039$, respectively). GzmB and IFN- $\gamma$ are key molecules associated with NK cell activation and were found to rise over a similar time-course with NK cell degranulation (Figure 8). Taken together, the results presented here indicate that lung-associated NK cells activate rapidly as a 

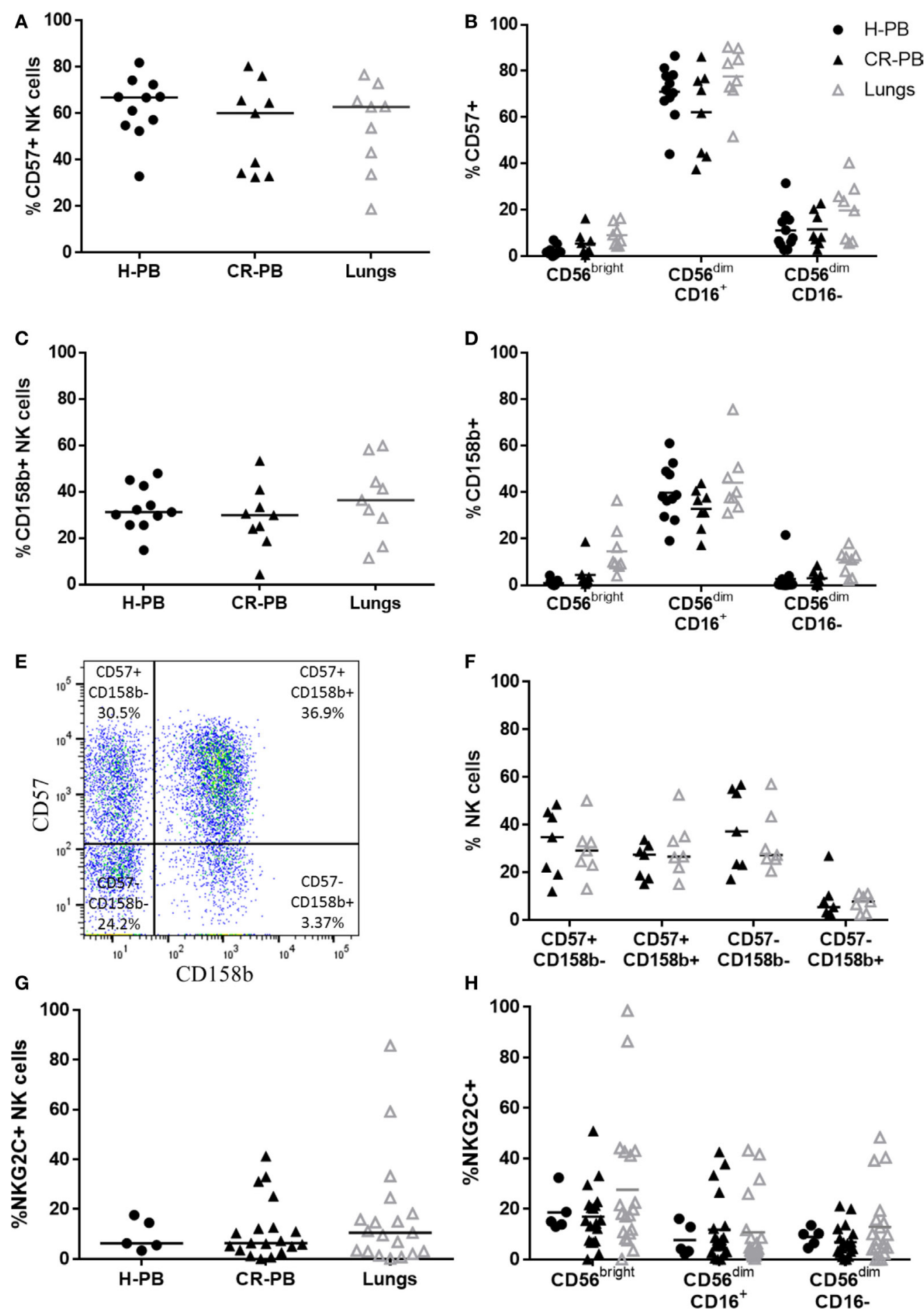

FIGURE 3 | CD57, CD158b, and NKG2C expression on lung and blood natural killer (NK) cells. CD57 (A) and CD158b (C) expression on NK cell subsets in peripheral blood of healthy controls [healthy peripheral blood $(\mathrm{H}-\mathrm{PB}) \mathrm{N}=11$ ] and peripheral blood [peripheral blood from cancer resection donor (CR-PB)] and lung of cancer resection patients $(N=9)$. Lines describe medians, comparison between healthy and resection blood by Mann-Whitney $U$ test and between lung and CR-PB by Wilcoxon signed-rank test. (B,D) CD57 and CD158b expression on CD56 bright, CD56 ${ }^{\text {dim }}$ CD16 $^{+}$, and CD56 dim CD16- NK cells from the blood and lung. Statistical analysis of H-PB to CR-PB by Kruskal-Wallis test with Dunn's multiple comparison correction and CR-PB to lung tissue by Friedman's test with Dunn's multiple comparison correction. (E) Representative flow cytometry plot describing lung NK cell CD57 and CD158b expression. (F) CD57 and CD158b expression on NK cells from the lung and matched blood [CR-PB (N=7)]. Statistical analysis by Friedman's test with Dunn's multiple comparison correction. (G) NKG2C expression on healthy controls $(N=5)$, cancer resection donor blood and lung tissue $(N=19)$. (H) NKG2C expression on CD56 ${ }^{\text {bright }}$, CD56 ${ }^{\text {dim }} C D 16^{+}$, and CD56 ${ }^{\text {dim }}$ CD16- NK cells from the blood and lung. 

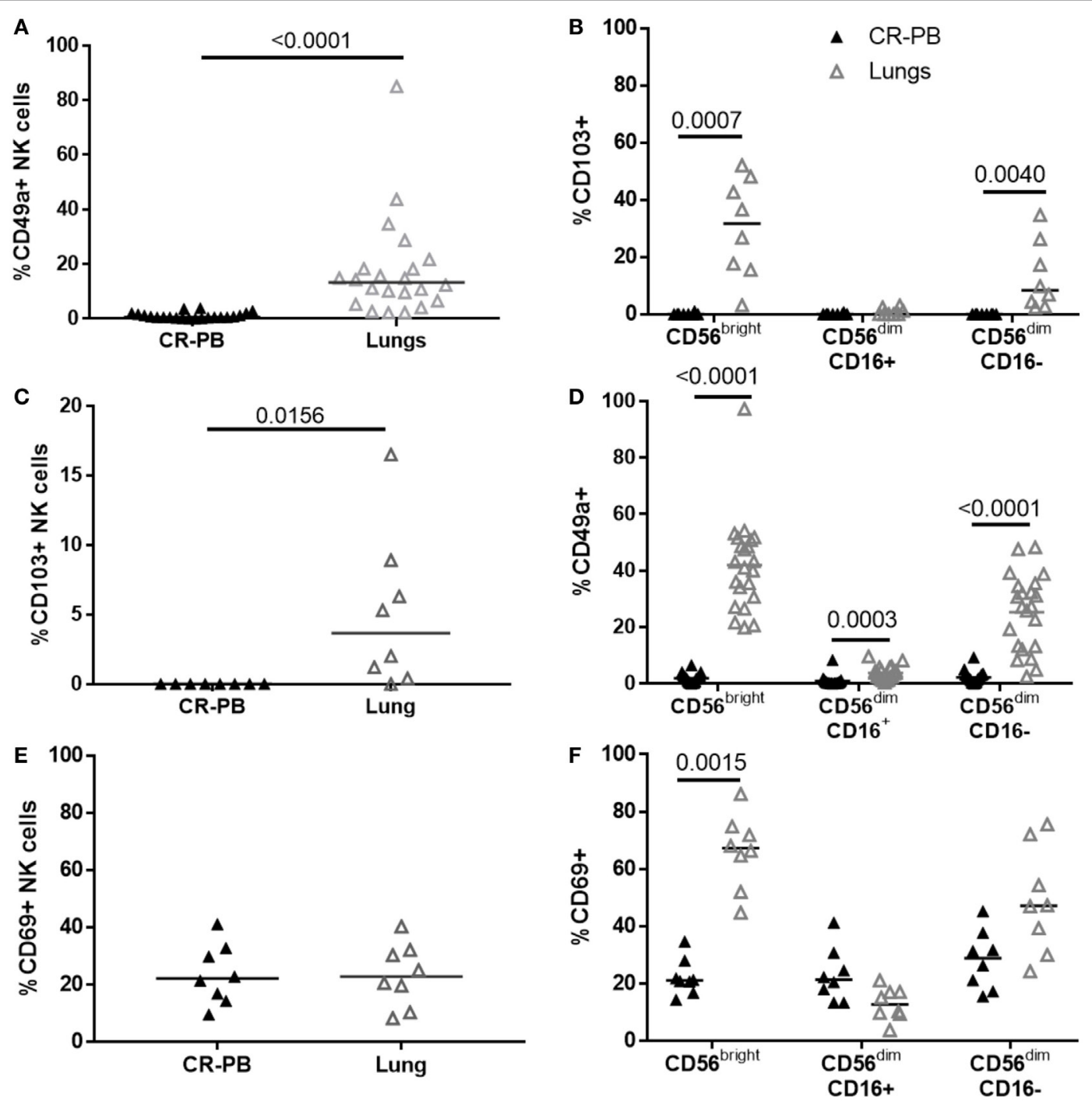

FIGURE 4 | Distinct natural killer (NK) cell populations are present in the blood, but not the lung. (A,C,E) Flow cytometric analysis of CD49a ( $N=22$ ), CD103 ( $N=8)$, and CD69 ( $N=8$ ) expression on lung and blood NK cells. Statistical analysis performed by Wilcoxon signed-rank test. Lines describe medians. (B,D,F) Residency marker expression on CD56 bright and CD56 dim NK cell subsets. Statistical analysis by Friedman's test with Dunn's multiple comparison correction.

result of ex vivo IAV infection. To further test if this was a discrete effect of NK cells or related to other cell types present in the explant model, we investigated the functional effects of NK cell activation in direct co-culture with infected macrophages.

\section{NK Cells Are Cytotoxic Toward IAV- Infected MDMs}

Airway macrophages were a target of H3N2 IAV infection in the explant lung model and have been shown to be critical to influenza control in mice (56-58). To investigate the effects of NK cell activation during IAV infection, we cultured peripheral blood NK cells with IAV-infected autologous MDMs. MDMs were differentiated to a lung-like phenotype, modeling airway macrophage activity and infected as described previously (45), resulting in a median of $29 \%$ of MDMs being positive for viral NP1 (Figure 9A). Following infection of the MDM monolayer, purified autologous NK cells were cultured with infected MDMs at an E:T ratio of 1:5 for 4-6 h resulting in increased NK cell degranulation ( $P=0.031$, Figure 9B). To assess NK cell cytotoxicity, MDM viability was measured by flow cytometry (Figures 9C,D). Co-culture with NK cells did not alter MDM viability when MDMs were uninfected (NT) or treated with UV-irradiated X31 (UV-X31) $(P=0.2158$ and $P=0.3848$, Figure 9D). Although some variation in the uninfected NK culture was observed, this was not found to be significantly different to either the NT MDMs alone or the UV-X31 exposed co-culture ( $P=0.2158$ and $P=0.1250$, respectively, Figure 9D). However, when MDMs were infected with live X31, MDM viability was reduced by $12 \%$ when NK cells were also present, 
A

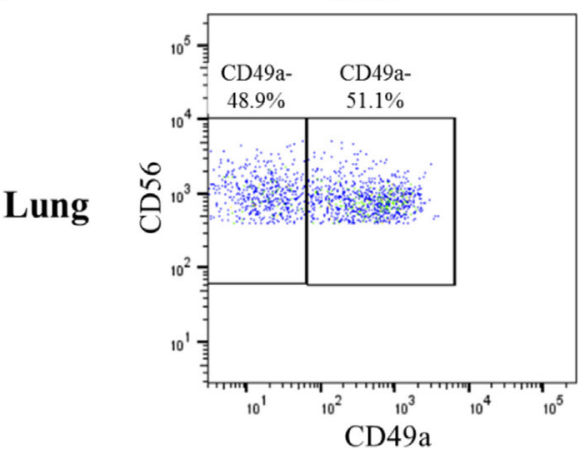

B

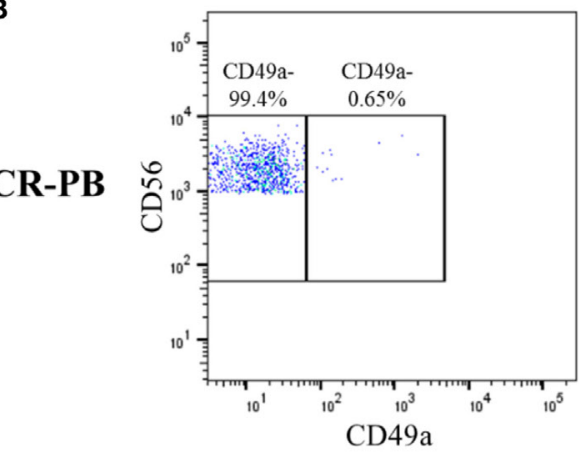

C

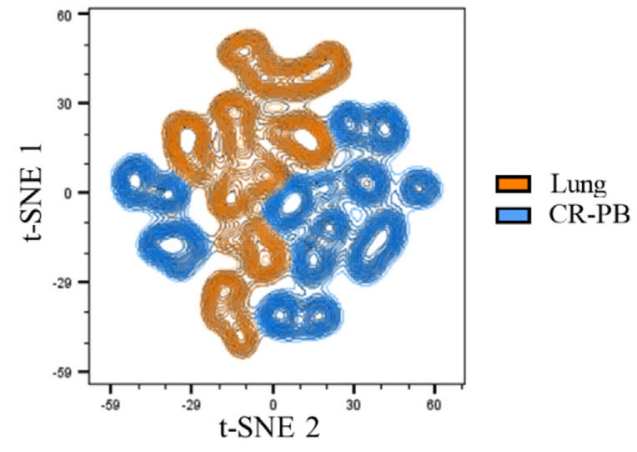

E

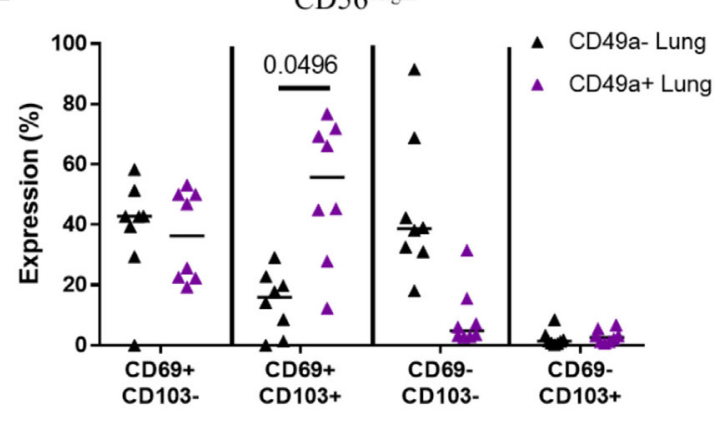

CD49a+CD56 ${ }^{\text {bright }}$
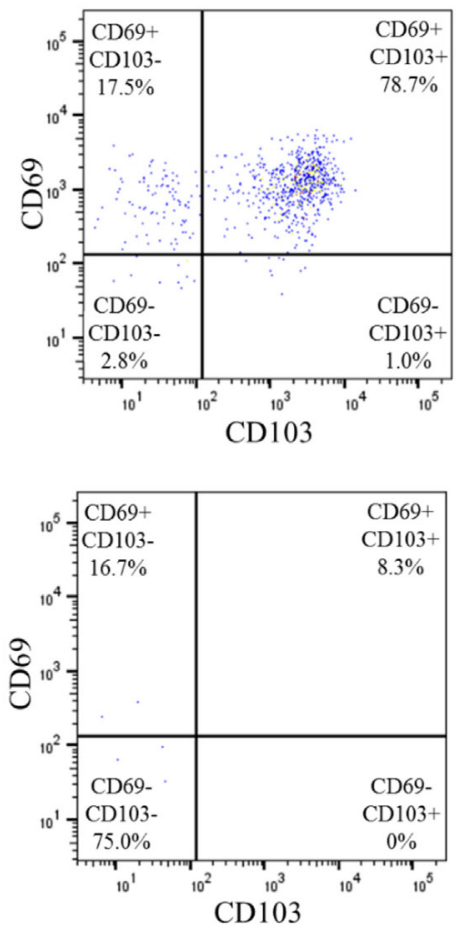

CD49a-CD56 ${ }^{\text {bright }}$
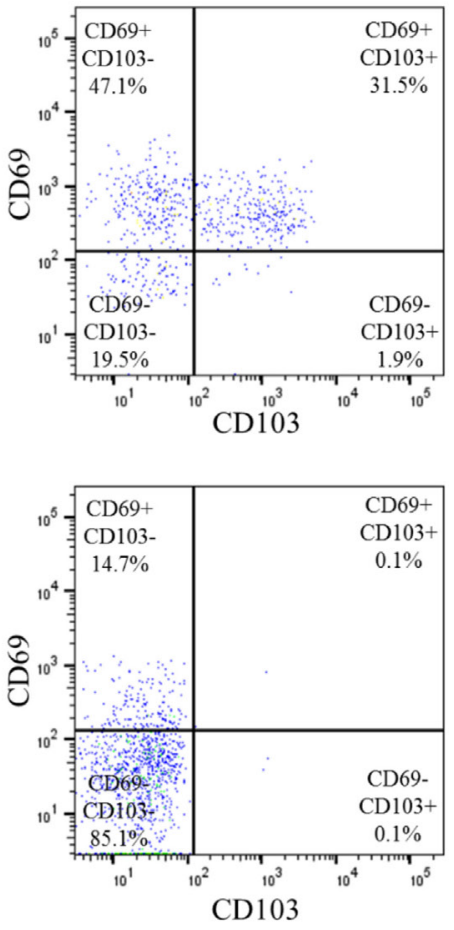

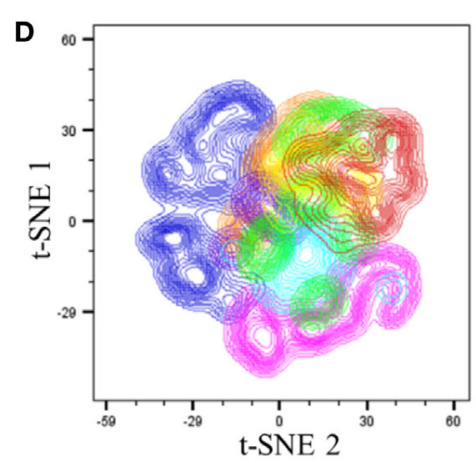

$\mathbf{F}$

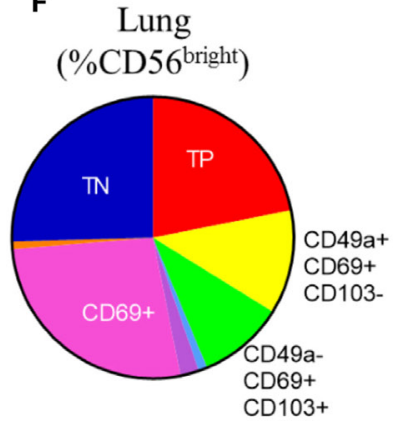

G

CR-PB

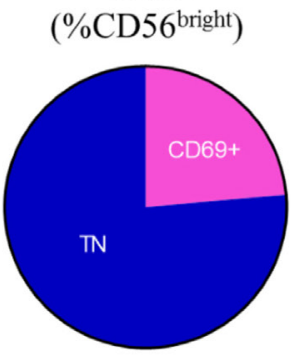

FIGURE 5 | CD56 bright CD49a+ lung natural killer (NK) cells co-express CD69 and CD103. (A,B) Gating strategy to define co-expression of CD69 and CD103 on $\mathrm{CD}_{49} \mathrm{a}^{+}$and $\mathrm{CD} 49 \mathrm{a}^{-}$populations of CD56 bight NK cells isolated from the lung (A) and blood [peripheral blood from cancer resection donor (CR-PB)] (B). (C) t-SNE plot of CD56 bright $N K$ cells in matched blood (blue) and lung (orange) based on CD49a, CD69, and CD103 expression ( $N=16,8$ individuals). From each sample, 300 events were randomly selected. Perplexity $=20,1,000$ iterations. (D) t-SNE plot of CD56 bright NK cells isolated from the lungs based on CD49a, CD69, and CD103 expression $(N=8)$. Cells are colored according to the expression of each marker, showing single-positive (SP), double-positive (DP), and triple-positive (TP) populations. From each sample, 600 events were randomly selected. Perplexity $=20,1,000$ Iterations. (E) Quantification of CD69 and CD103 expression of CD49a ${ }^{+}$ and CD49a-CD56 bright NK cell populations of the lung and blood. Lines described medians, statistical analysis by Friedman's test with Dun's correction ( $N=8)$. Overall $P$-value $<0.001$. (F,G) Quantification of residency marker expression on CD56 bright $N K$ cells of matched blood (F) and lung (G). Key as shown in panel (D). 

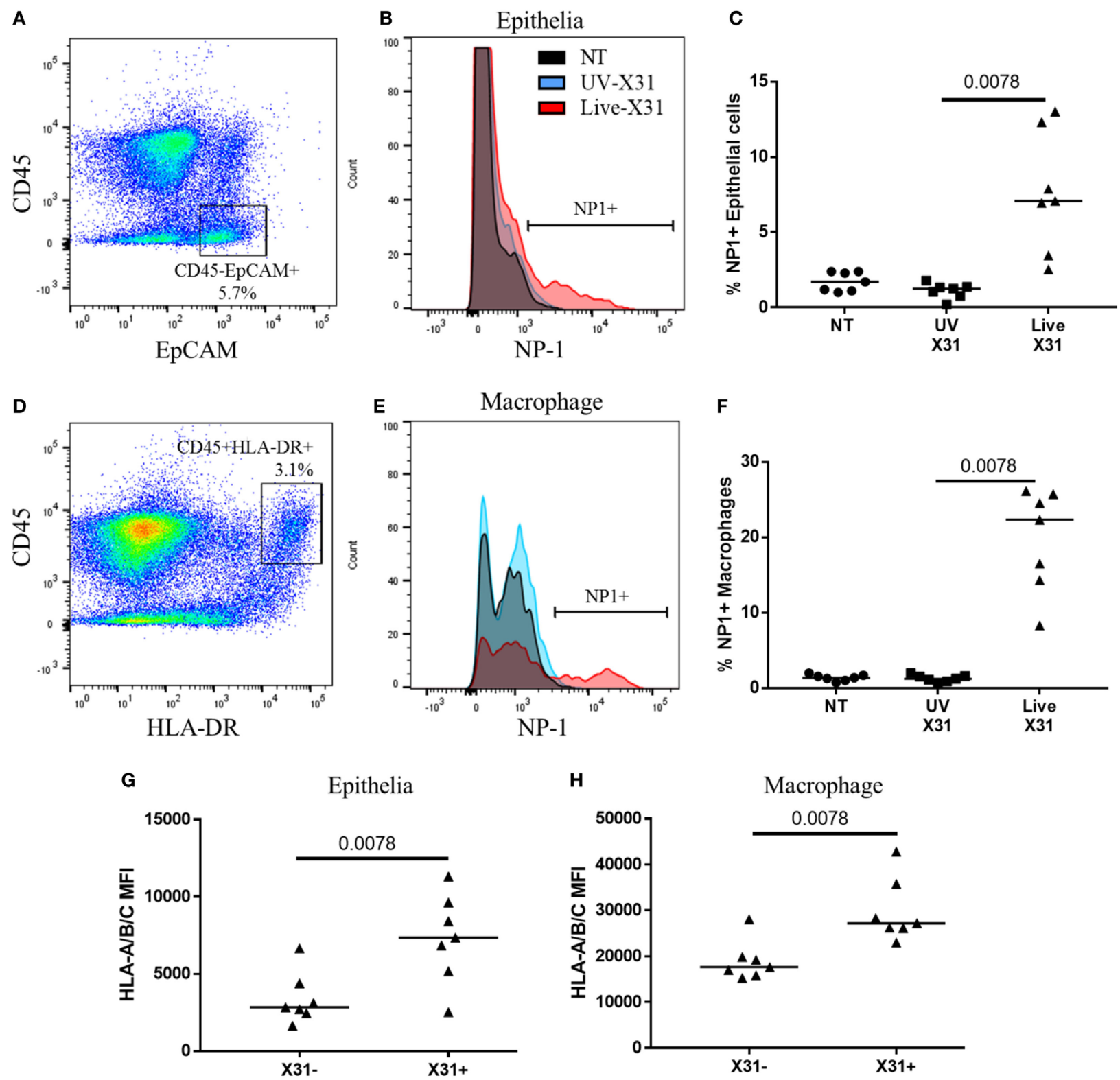

FIGURE 6 | Influenza X31 infection in human lung explants. (A) Representative flow cytometry plot defining lung epithelia as CD45-EpCAM+ cells. (B,C) Influenza nucleoprotein-1 (NP1) expression in X31-infected epithelia. (D) Representative flow cytometry plot defining lung macrophages as CD45+HLA-DR+ cells. (E,F) Influenza NP1 expression in X31-infected macrophages. (G,H) Expression of HLA-A/B/C on epithelial cells (G) and macrophages (H) with and without X31 infection, as defined by NP1 expression. Lines describe medians, statistical analyses performed by Wilcoxon signed-rank test $(N=7)$.

relative to MDMs alone $(P=0.0029$, Figure $9 D)$. MDM viability was also reduced relative to UV-X31 treated co-culture and uninfected co-culture ( $P=0.0420$ and $P=0.0186$, Figure 9D) indicating that NK cells exerted a cytotoxic effect following live X31 infection.

\section{NK Cell Contact With Infected Cells Determines NK Cell Activation}

Culture of purified autologous NK cells with IAV-infected MDMs induced NK cell expression of antiviral molecules such as GzmB and IFN- $\gamma$, as detected by flow cytometry (Figures 10A,B; Figure S2 in Supplementary Material). Indeed, extracellular IFN- $\gamma$ was only observed when NK cells were cultured with X31-infected MDMs ( $P=0.0078$, Figure 10D). In addition, there was a non-significant trend toward increased extracellular GzmB in X31-infected co-cultures $(P=0.055$, Figure 10E). CD56 ${ }^{\text {bright }}$ and $\mathrm{CD}^{\mathrm{dim}} \mathrm{NK}$ cells responded equivalently to culture with X31-infected MDMs, with all subsets producing IFN- $\gamma$ (Figure 10C). These results suggest both cytokines and cytotoxic molecules are released by NK cells following contact with influenza-infected cells. 


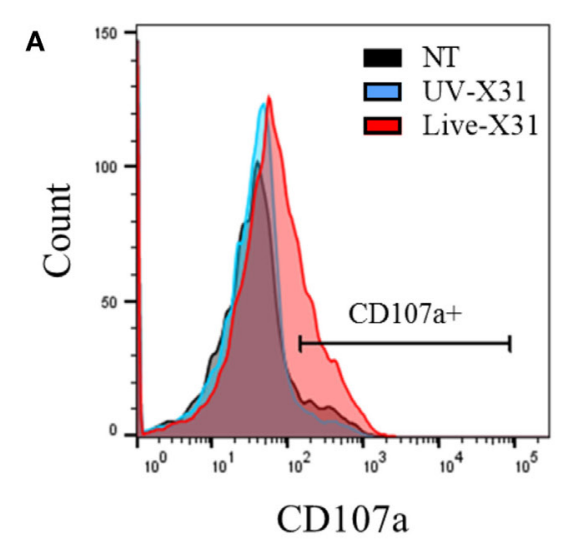

B

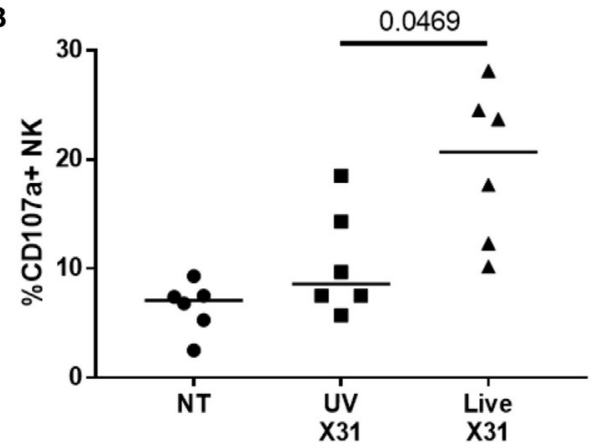

D
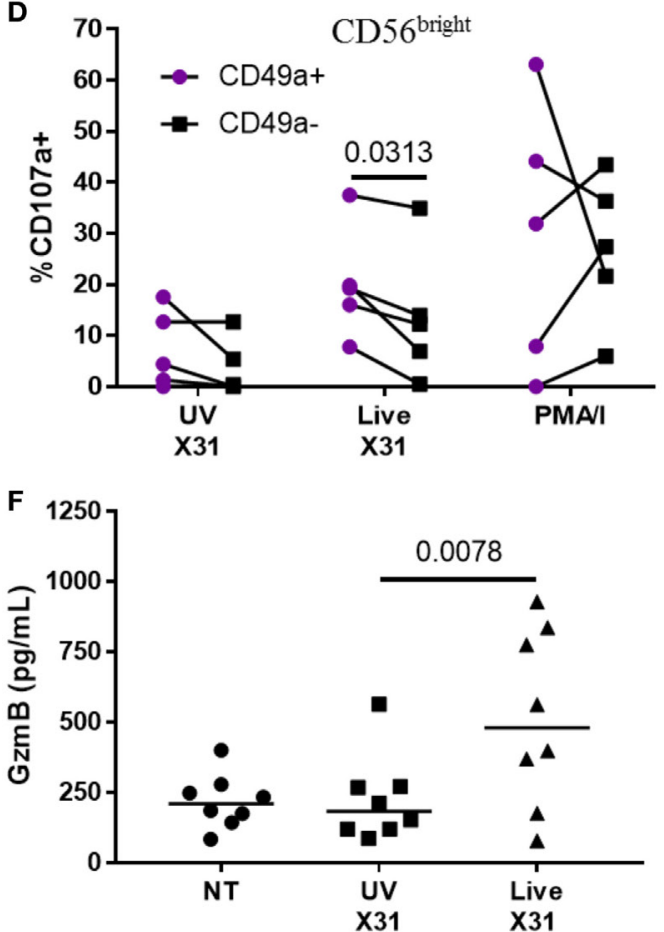

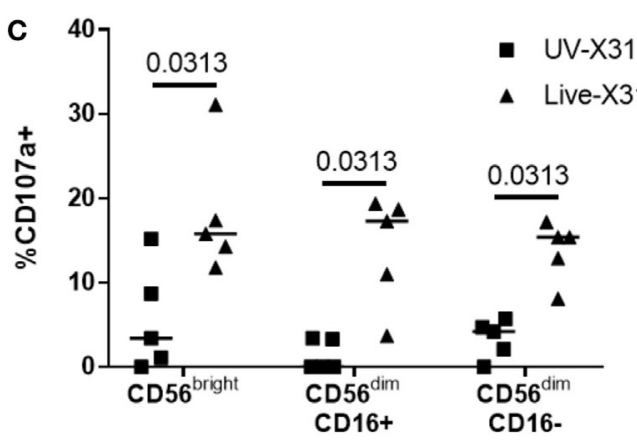

E
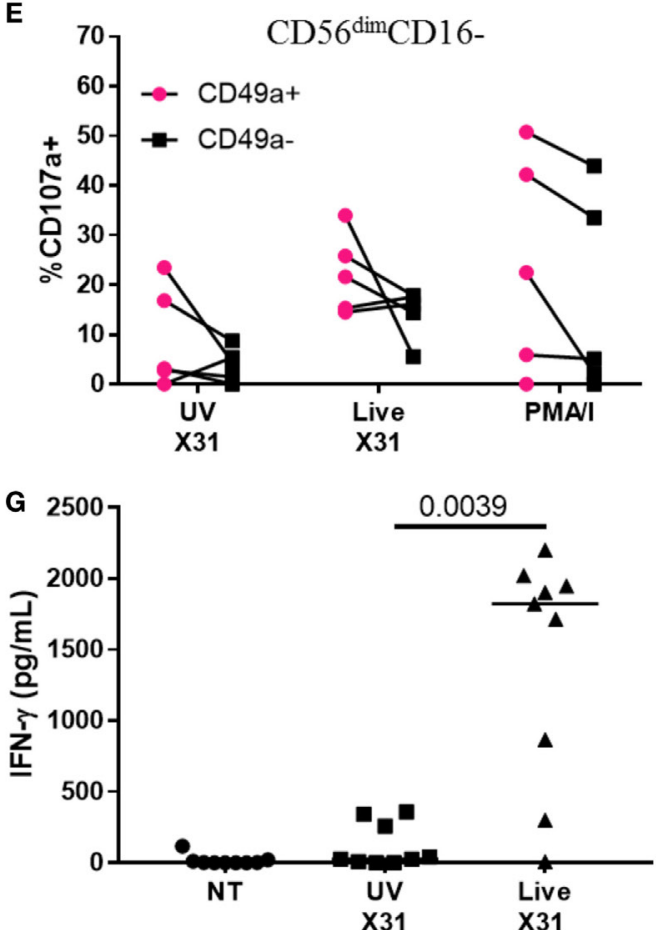

FIGURE 7 | Natural killer (NK) cell activation in X31-infected human lung explants. (A,B) Representative flow plot and quantification of surface CD107a on explant NK cells 24 hpi $(N=6)$. (C) Surface CD107a on NK cell subsets $24 \mathrm{~h}$ after X31 infection $(N=5)$. Uninfected (NT) background CD107a expression was subtracted. $(\mathbf{D}, \mathbf{E}) \mathrm{CD} 49 \mathrm{a}^{+}$and C49a- NK cell degranulation of CD56 bright $(\mathbf{D})$ and CD56 ${ }^{\text {dim }} \mathrm{CD} 16^{-}$(E) NK cells following X31 infection and phorbol myristate acetate/ionomycin stimulation of lung explants $(N=6)$. ( $(F, G)$ Extracellular granzyme-B $(G z m B)$ and IFN- $\gamma$ in explant supernatants 24 h post-infection with X31 ( $N=8)$. Lines describe medians, statistical analysis performed by Wilcoxon signed-rank test. 

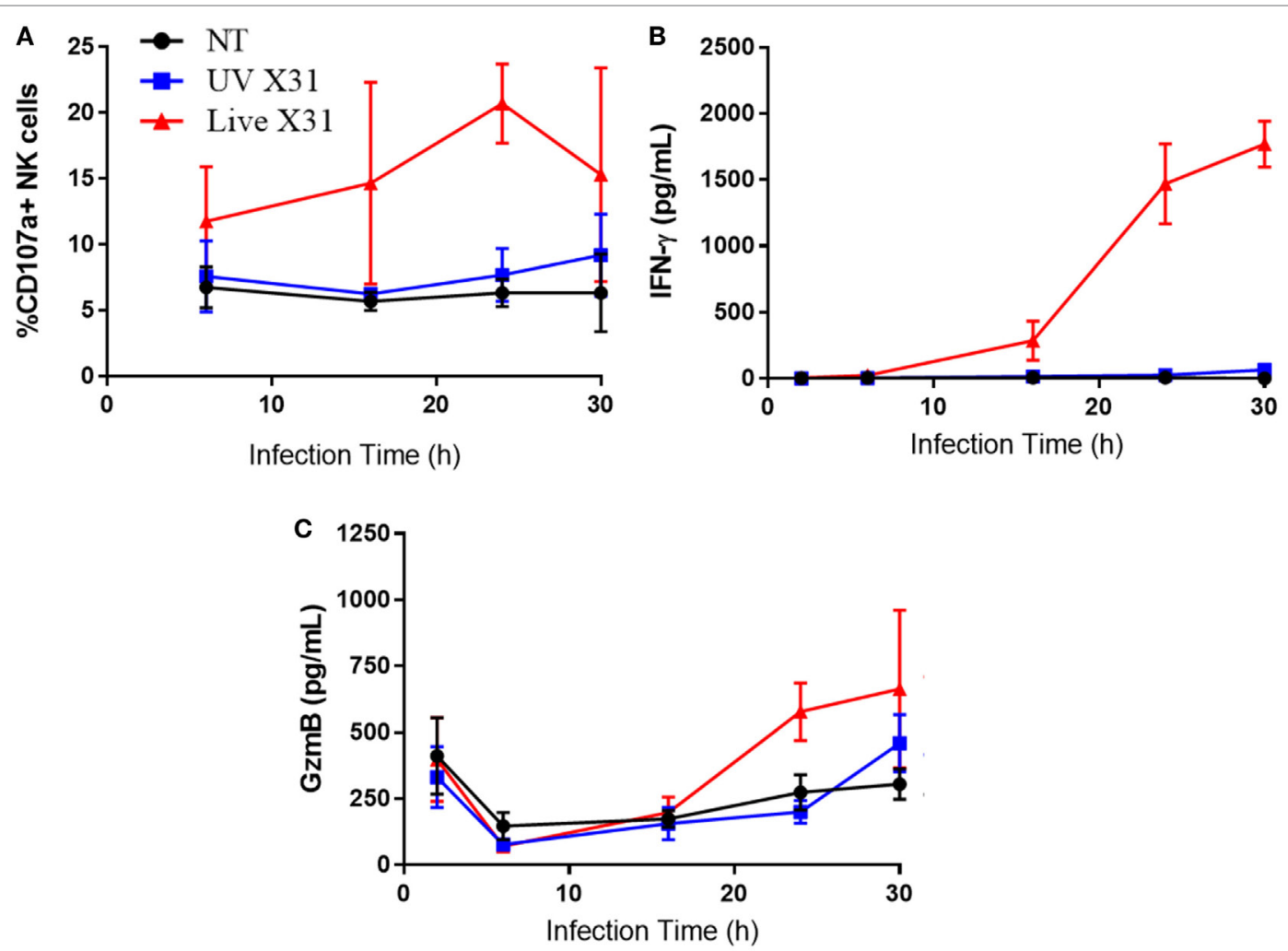

FIGURE 8 | Explant response to X31 infection over time. (A) Natural killer (NK) cell surface expression of CD107a. (B,C) Extracellular secretion of IFN- $\gamma$ (B) and granzyme-B (C) from infected lung tissue $(N=3$, except $6 \mathrm{~h} N=2)$. Lines describe mean and SEM.

Direct contact between NK cells and MDMs was essential for NK cell activation as separation of the two cells in a transwell system abrogated both GzmB production and IFN- $\gamma$ release (Figure 10). This suggests that changes to the MDM surface as a result of IAV infection may determine NK cell activation. HLA class I molecules play an important role in governing NK cell responses and are upregulated on IAV-infected lung epithelial cells and macrophages (Figures 6H,I and 11A). To investigate the effect of this change in surface HLA, HLA class I ligands on human MDMs were blocked with anti-HLA$\mathrm{A} / \mathrm{B} / \mathrm{C}$ (clone W6/32) prior to culture with NK cells. Blocking with $\alpha$ HLA-ABC or isotype control did not affect NK cell activation in response to uninfected MDMs, suggesting that this antibody does not induce antibody-dependent cellular cytotoxicity (Figure 11B). However, during culture with X31-infected MDMs, blocking class I HLA increased NK cell CD107a expression $(P=0.031)$ indicating that HLA class I has inhibitory effects on $\mathrm{NK}$ cells during live influenza infection (Figure 11C). Despite this, NK cells still activate in response to influenza-infected cells, suggesting the balance between NK cell activatory and inhibitory signaling is perturbed during contact with IAV-infected cells. These results suggest that NK cells are capable of a strong antiviral response following contact with influenza-infected cells, with production and release of IFN- $\gamma, \mathrm{GzmB}$, and significant cytotoxicity against infected macrophages.

\section{DISCUSSION}

The role of NK cells in tissue-specific responses is being increasingly recognized as they may represent an important early front-line defense during respiratory infection $(32,35)$. In this study, we have explored the NK cell response to influenza infection of human lung parenchyma and MDMs. We identified early activation of NK cells in response to influenza-infected cells, including IFN- $\gamma$ and GzmB production, degranulation, and cytotoxicity. In addition, for the first time, we demonstrate NK cell-mediated destruction of influenza-infected macrophages, indicating that $\mathrm{NK}$ cells may have an important role in regulating the effects of antigen-presenting cells during IAV infection $(59,60)$.

To explore the ex vivo function of human lung NK cells, $\mathrm{NK}$ cells were defined as $\mathrm{CD} 45^{+} \mathrm{CD} 3^{-} \mathrm{CD} 56^{+}$cells, a gating strategy designed to exclude innate lymphoid cell (ILC) populations. Although a small population of ILC3s may be included in our analysis (50\% of $\mathrm{NCR}^{-}$ILC3s express CD56) the total human lung ILC3 population comprise less than $0.025 \%$ of $\mathrm{CD}^{+} 5^{+}$ cells and therefore would make a minimal contribution to our analysis $(61,62)$. However, consistent with previous reports, $\mathrm{CD} 6^{+} \mathrm{CD}^{-} \mathrm{NK}$ cells made up a significant proportion $(18.55 \%)$ of $\mathrm{CD} 45^{+}$lymphocytes in the human lung and were found to be predominantly mature, canonical NK cells, corroborating the work by Marquardt et al. (37-39). 

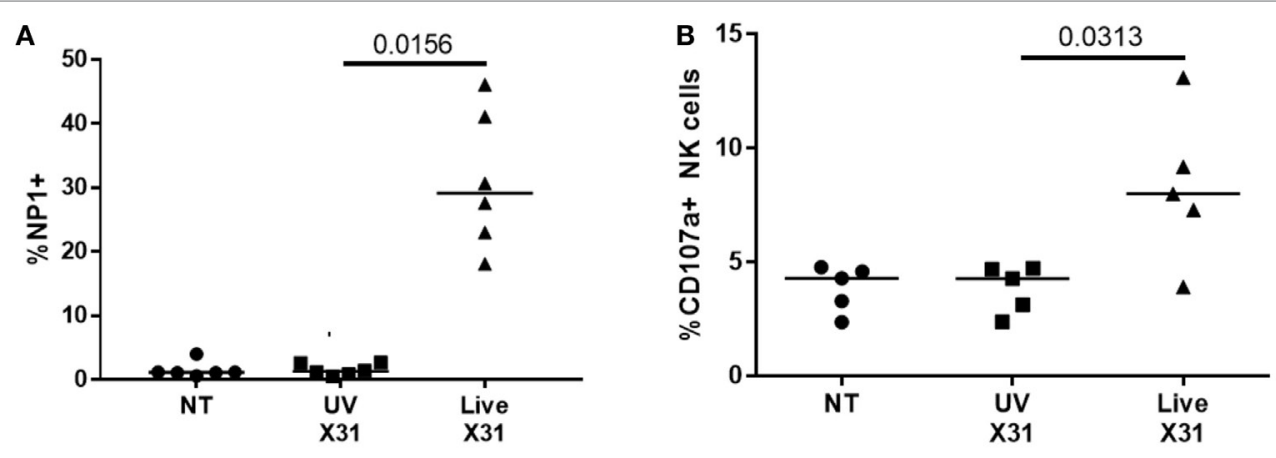

C

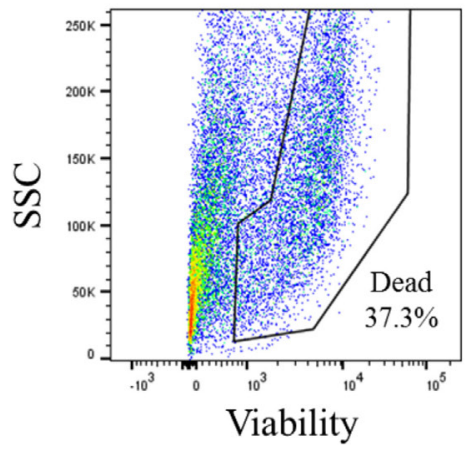

D

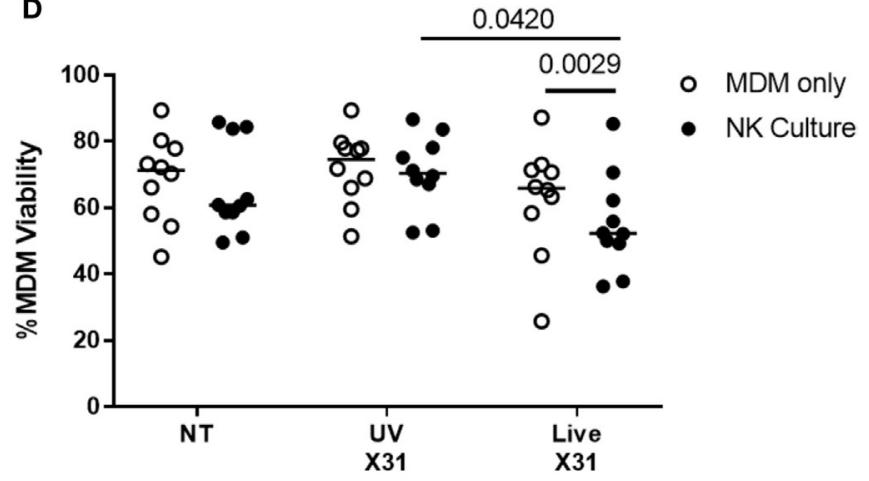

FIGURE 9 | Peripheral blood natural killer (NK) cells are cytotoxic toward X31-infected cells. (A) X31 infection of monocyte-derived macrophages (MDMs) was determined by flow cytometric analysis of nucleoprotein-1 (NP1) expression $(N=6)$. (B) Uninfected (NT), UV-irradiated X31, and live X31-infected MDMs were cultured with autologous peripheral blood NK cells for 4-6 h. NK cell degranulation was determined by flow cytometric analysis of surface CD107a ( $N=5$ ). (C,D) Following culture with NK cells, MDM viability was measured by uptake of amine-binding dye and analyzed by flow cytometry $(N=10)$. Representative gating for MDM viability. Fixable dead stain, viability gating defined through heat-killed control. (C) Representative gating of X31-infected MDM viability. Lines describe medians, statistical analysis by Wilcoxon signed-rank test.

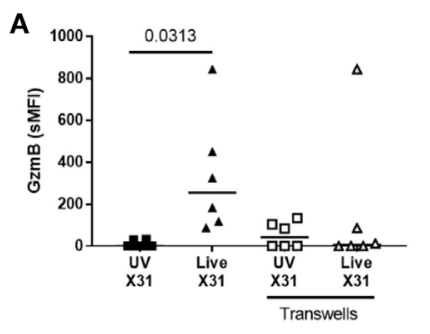

D

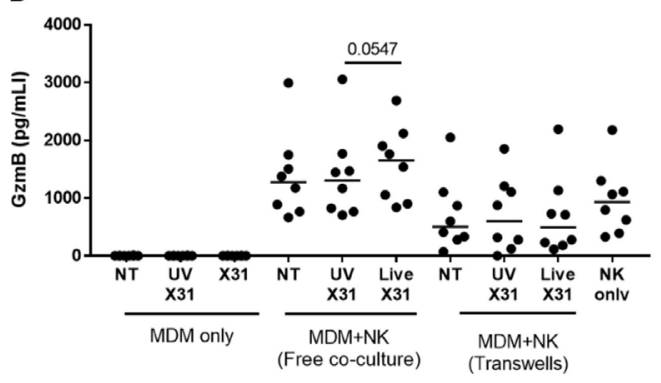

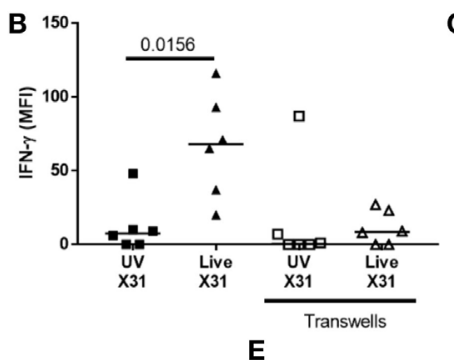

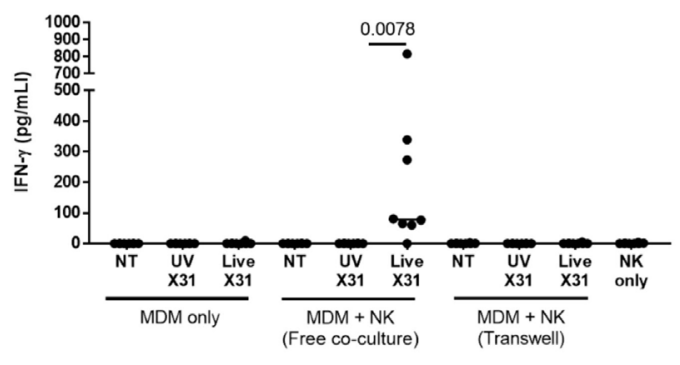

FIGURE 10 | Peripheral blood natural killer (NK) cells produce IFN- $\gamma$ and granzyme-B (GzmB) after contact with X31-infected cells. (A,B) Intracellular accumulation of GzmB and IFN- $\gamma$ was measured by flow cytometry $6 \mathrm{~h}$ after culture with X31-infected monocyte-derived macrophages (MDMs). Physical separation of MDMs and NK cells in a transwell system abrogated IFN- $\gamma$ and GzmB production $(N=6)$. (C) Intracellular IFN- $\gamma$ of CD56 bright and CD56 dim NK cell subsets when cultured with MDMs treated with UV-irradiated X31 and live-X31. (D,E) Extracellular secretion of GzmB (D) and IFN- $\gamma$ (E). Lines describe medians, statistical analysis by Wilcoxon signed-rank test. 

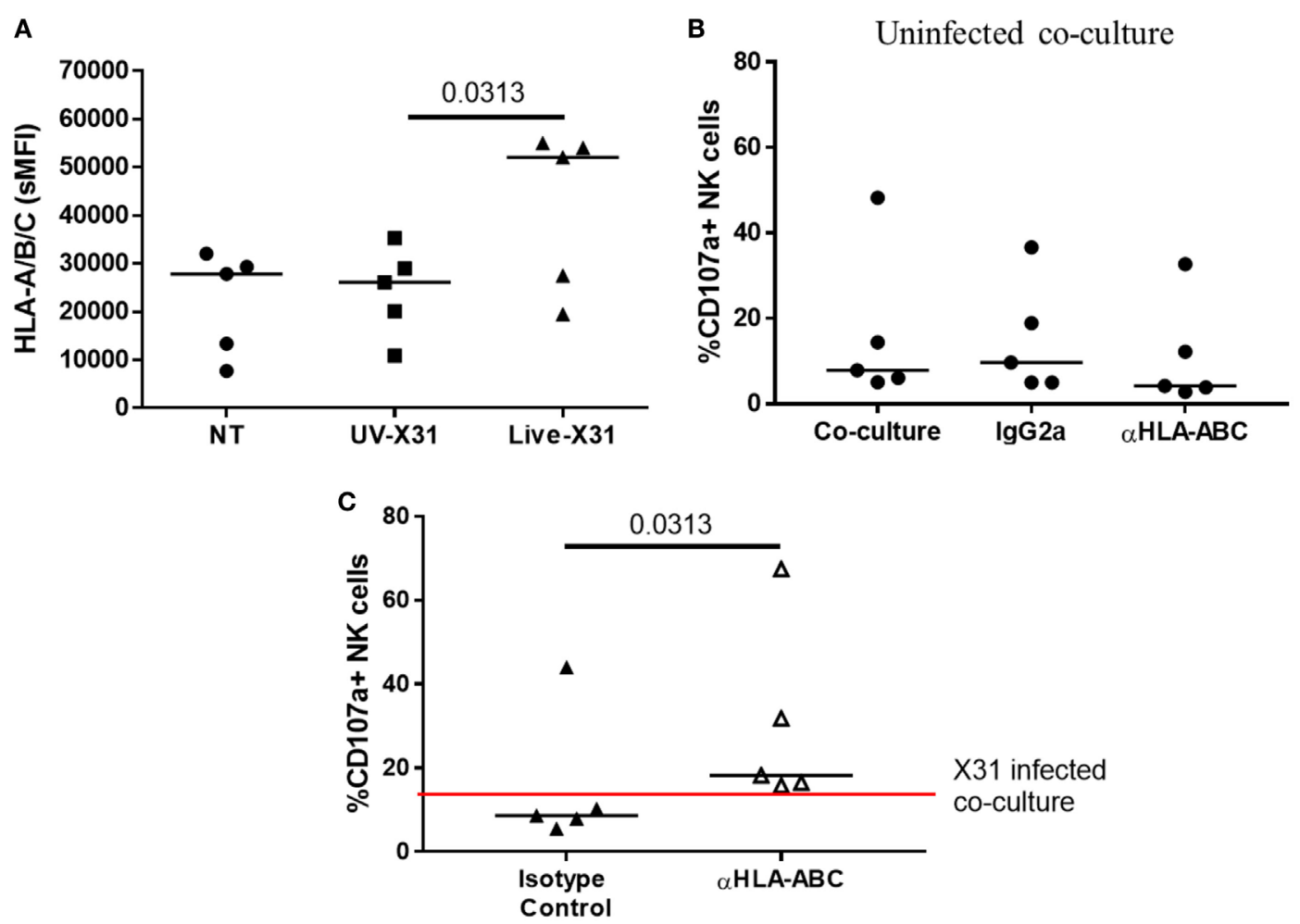

FIGURE 11 | Blocking class I HLA increases natural killer (NK) cell degranulation during culture with X31-infected macrophages. (A) Monocyte-derived macrophage (MDM) HLA-A/B/C expression $24 \mathrm{~h}$ after uninfected (NT) UV-irradiated and live X31 infection $(N=5)$. (B) Background NK cell degranulation following culture with uninfected macrophages when macrophages were treated with $\alpha \mathrm{HLA}$ or isotype control for 20 min prior to addition of NK cells (lgG2a) ( $N=5$ ). (C) $24 \mathrm{~h}$ postinfection MDMs were incubated with antibody against HLA-A/B/C for 20 min prior to co-culture with NK cells. NK cell degranulation was measured by flow cytometry $(N=5)$. Lines describe medians. Statistical analyses performed by Wilcoxon signed-rank test.

Understanding the lung NK cell phenotype is important for understanding NK cell function during pulmonary health and disease. The differentiated and active NK cell phenotype described for NK cells both here and by Marquardt et al. (39) is interesting as unchecked cytotoxicity in this setting may have the capacity to impair lung function $(39,63)$. Indeed, NK cells taken from people with chronic obstructive pulmonary disease (COPD) were found to be more cytotoxic toward airway epithelia, a functional change which appeared intrinsic to the NK cell, indicating an altered activation state in this disease (63). NK cells isolated from the lungs have often been reported as hypofunctional following stimulation with PMA or K562 cell lines, a finding which might reflect important mechanisms of NK cell regulation in the pulmonary environment (36-39). Yet in this study, IAV infection of human lung explants was sufficient to activate NK cell degranulation. Both CD56 $6^{\text {bright }}$ and CD56 dim NK cells were found to activate rapidly in response to IAV, indicating that NK cells may aid early virus control within the lung.

As the lungs are a highly vascularized organ, it is possible that the NK cells examined by this study may have been passing through the lungs during circulation (39). Indeed, the phenotype of lung-associated NK cells is more similar to the NK cells of the peripheral blood than other human organs $(30,31$, $33,34)$. Although we cannot exclude the possibility that the phenotype reported in our study comes from the peripheral blood, the tissue was washed extensively and rested to remove contaminating blood cells prior to analysis. Analysis of the $\mathrm{T}$ cell phenotype in lung tissue utilizing this method supports this ability to remove blood lymphocytes, as only memory $\mathrm{T}$ cells are isolated from this organ with little to no presence of naïve $\mathrm{T}$ cells (64). Moreover, we have identified a novel $\mathrm{CD} 49 \mathrm{a}^{+} \mathrm{CD} 69^{+} \mathrm{CD} 103^{+} \mathrm{NK}$ cell population from the human lung parenchyma not found in the blood. Interestingly, the lung possessed more $\mathrm{CD} 49 \mathrm{a}^{+} \mathrm{NK}$ cells compared with reports from the human liver (31).

To investigate the function of human lung CD49a ${ }^{+} \mathrm{NK}$ cells, we analyzed the CD107a expression of $\mathrm{CD} 56^{\text {bright }} \mathrm{CD} 49 \mathrm{a}^{+}$ NK cells (Figure 7). We observed that a greater proportion of $\mathrm{CD} 56^{\text {bright }} \mathrm{CD} 49 \mathrm{a}^{+} \mathrm{NK}$ cells activate in response to IAV infection compared with $\mathrm{CD} 56^{\text {bright }} \mathrm{CD} 49 \mathrm{a}^{-} \mathrm{NK}$ cells, an effect not seen with PMA/I stimulation. This suggests that $\mathrm{CD} 56^{\text {bright }} \mathrm{CD} 49 \mathrm{a}^{+}$ NK cells may respond specifically to viral infection as the total potential of $\mathrm{CD} 56^{\text {bright }} \mathrm{CD} 49 \mathrm{a}^{+} \mathrm{NK}$ cells is not dissimilar to CD56 ${ }^{\text {bright }} \mathrm{CD} 49 \mathrm{a}^{-}$. Lung CD49a $\mathrm{a}^{+}$NK cells may therefore represent a population of resident NK cells that can be induced to express a more robust recall response following prior exposure to common respiratory pathogens, such as IAV. Indeed, liver $\mathrm{CD} 49 \mathrm{a}^{+} \mathrm{NK}$ cells generated in influenza-infected mice were 
protective following adoptive transfer and subsequent influenza challenge, although murine lung CD49a ${ }^{+}$NK cells were not protective in this model (40). These experiments indicate that NK cell memory of influenza infection could exist within the adult human lung, although this requires further corroboration through analysis of transcription factor expression and epigenetic state. If so, the generation of such local mucosal immunity may have important implications for vaccine design, offering a possibility for increasing strain cross-reactivity and effectiveness (35). However, the full functional role of this $\mathrm{CD} 56^{\text {bright }} \mathrm{CD} 49 \mathrm{a}^{+}$population and the governing mechanisms remain to be elucidated.

As expected $\mathrm{CD} 56^{\mathrm{dim}} \mathrm{CD} 16^{-} \mathrm{CD} 49 \mathrm{a}^{+}$lung $\mathrm{NK}$ cells were not found to be more responsive to $\mathrm{X} 31$ infection, a finding that fits with the literature as only CD56 ${ }^{\text {bright }}$ populations have been associated with residency $(30,31,33,34)$. Some authors have suggested that $\mathrm{CD} 56^{\mathrm{dim}} \mathrm{CD} 16^{-} \mathrm{NK}$ cells represent contaminating $\mathrm{CD}^{+}{ }^{+} \mathrm{CD} 56^{+} \mathrm{NKT}$ cells $(65,66)$. However, as $\mathrm{CD}^{+}$cells were specifically excluded from our analysis (Figure 1), we consider it more likely that this population represents activated NK cells that have undergone CD56 and CD16 shedding (66-69). Therefore, $\mathrm{CD} 56^{\mathrm{dim}} \mathrm{CD} 16^{-} \mathrm{CD} 49 \mathrm{a}^{+}$lung NK cells might represent functionally exhausted $\mathrm{CD} 56^{\text {bright }} \mathrm{CD} 49 \mathrm{a}^{+}$cells. Interestingly, $\mathrm{CD} 56^{\text {dim }} \mathrm{CD} 16^{-} \mathrm{NK}$ cells were also expanded in the peripheral blood of donors undergoing resection surgery when compared with healthy controls. A finding which may be due to demographic differences between the cohorts. Our preliminary data suggest that age did not affect the proportion of $\mathrm{CD} 56^{\mathrm{dim}} \mathrm{CD} 16^{-} \mathrm{NK}$ cells (Figure 2); however, we cannot rule out an effect of disease and smoking status on the NK cell phenotype (39).

Natural killer cell effector molecules IFN- $\gamma$ and GzmB were produced by influenza-infected explants 24 hpi (Figure 8). The length of time taken in generating both IFN- $\gamma$ and GzmB by X31-infected tissue could suggest that this is a secondary response to initial inflammatory signaling through IFN- $\alpha$ and IFN- $\beta$, as there is some support for this in the literature $(70,71)$. Interestingly, extracellular GzmB appeared to wane by $6 \mathrm{hpi}$, only to rise again at $24 \mathrm{hpi}$ in live X31-infected tissue. However, at the $2 \mathrm{~h}$ timepoint, extracellular GzmB was greater in all conditions including uninfected (NT) tissue, this suggests that GzmB release at this time-point may be a result of explant removal from the body or tissue preparation, as explants were washed prior to exposure to virus.

Natural killer cell IFN- $\gamma$ production and release was also measured from co-cultures with X31-infected MDMs and NK cells, an effect that was dependent on contact between the two cell types (Figure 10). Although CD56 ${ }^{\text {bright }}$ NK cells have been suggested to dominate NK cell cytokine production, both CD56 ${ }^{\text {bright }}$ and CD56 ${ }^{\text {dim }}$ NK cells produced IFN- $\gamma$ when MDMs were infected with live X31, suggesting that there may be a common mechanism of activation between the two subtypes toward influenza $(11,72)$. This could include the NKp46 or NKG2D activating receptors as well as activating or inhibitory KIR (16-18). However, these molecules are differentially expressed by CD56 $6^{\text {bright }}$ and CD56 $6^{\text {dim }} \mathrm{NK}$ cells, and it is possible that NK cell subsets are activated by different mechanisms during influenza infection $(12,50)$. Interestingly, GzmB release appeared less dependent on contact between NK cells and infected MDMs; however, as GzmB is released within the immune synapse this could limit detection of changes in the amount of this molecule. Although the differences between cells treated with UV-X31 and live X31 have not been thoroughly explored here, no NK cell response was observed toward UV-infected macrophages, either in the tissue explant or MDM infection. This suggests that NK cells are responding to changes on the target cell, in response to the intracellular replication of live influenza.

The upregulation of HLA class I molecules during IAV infection appeared to be inhibitory to NK cells, as blocking HLA class I increased NK cell degranulation. This might represent viral evasion of the NK cell response (73). Alternatively, HLA class I upregulation could also reflect a host strategy for increased antigen presentation to $\mathrm{CD}^{+} \mathrm{T}$ cells. An inhibitory role of the HLA class I suggests that NK cell activation of IAV-infected cells may depend on upregulation of concomitant ligands for activating receptors, such as NKp46 and NKG2D on the target cell surface (16-18). Interestingly, cigarette smoke has been shown to prime the NK cell response to viral infection through increased expression of NKG2D ligands in a murine model of COPD (74). Unfortunately, due to flow cytometry channel limits, it was not possible to investigate tissue ligand expression in the experiments presented here.

Cancer resection is one of the few available sources of human lung tissue, but disease state, smoking history, and medication remain confounding factors in the use of this material (39). Furthermore, the heterogeneity between individuals is reflected in the range of NK cell functional responses and marker expression. Despite these caveats, the NK cell phenotype from the human lung is consistent with healthy mice in terms of maturity and differentiation, and functional results were further confirmed in a co-culture model of IAV infection $(37,38)$. Analysis of human lung-resident NK cell populations would not be possible without human lung tissue and ex vivo infection enables the characterization of NK cell function in a relevant context of human disease.

In conclusion, we identify a unique and putative resident $\mathrm{CD}^{6} 6^{\text {bright }} \mathrm{CD} 49 \mathrm{a}^{+}$lung $\mathrm{NK}$ cell population which underwent greater levels of activation during IAV infection. We speculate that $\mathrm{CD} 49 \mathrm{a}^{+} \mathrm{NK}$ cells could represent a lung-resident population of NK cells trained by the respiratory environment. Further exploration of this NK cell phenotype is required to understand whether such local mucosal immunity could be manipulated to broaden IAV vaccine cross-reactivity and efficacy. As NK cells make up around a quarter of parenchymal lymphocytes and respond rapidly to IAV infection, NK cells may be well placed to provide early and broad innate immunity to IAV infection in humans.

\section{ETHICS STATEMENT}

This study was approved by Southampton and South West Hampshire Research Ethics Committees (13/SC/0416 for healthy control group, 09/H0504/109 for resection and blood donors, 15/SC/0528 for age comparison). All participants provided 
written informed consent in accordance with the Declaration of Helsinki.

\section{AUTHOR CONTRIBUTIONS}

Data acquisition, analysis, and interpretation were provided by GC, KO, and KS. All the authors contributed to the drafting of manuscript for important intellectual content and manuscript conception and design.

\section{ACKNOWLEDGMENTS}

The authors wish to thank Richard Jewell and Dr. Carolann MacGuire of the University of Southampton, Faculty of Medicine, Flow Cytometry Unit. We would also like to express our appreciation to Benjamin Johnson, Carine Fixmer, and the rest of the

\section{REFERENCES}

1. Taubenberger JK, Kash JC. Influenza virus evolution, host adaptation, and pandemic formation. Cell Host Microbe (2010) 7(6):440-51. doi:10.1016/j. chom.2010.05.009

2. Stohr K. Influenza - WHO cares. Lancet Infect Dis (2002) 2(9):517. doi:10.1016/ S1473-3099(02)00366-3

3. Greenberg HB, Piedra PA. Immunization against viral respiratory disease: a review. Pediatr Infect Dis J (2004) 23(11 Suppl):S254-61. doi:10.1097/01. inf.0000144756.69887.f8

4. Mossad SB. Influenza: still more important than Zika virus in 2016-2017. Cleve Clin J Med (2016) 83(11):836-40. doi:10.3949/ccjm.83a.16105

5. Krammer F, Palese P. Advances in the development of influenza virus vaccines. Nat Rev Drug Discov (2015) 14(3):167-82. doi:10.1038/nrd4529

6. Romagnani C, Juelke K, Falco M, Morandi B, D’Agostino A, Costa R, et al. CD56brightCD16- killer Ig-like receptor- NK cells display longer telomeres and acquire features of CD56dim NK cells upon activation. J Immunol (2007) 178(8):4947-55. doi:10.4049/jimmunol.178.8.4947

7. Wong MT, Ong DE, Lim FS, Teng KW, McGovern N, Narayanan S, et al. A high-dimensional atlas of human $\mathrm{T}$ cell diversity reveals tissue-specific trafficking and cytokine signatures. Immunity (2016) 45(2):442-56. doi:10.1016/j.immuni.2016.07.007

8. Vivier E, Tomasello E, Baratin M, Walzer T, Ugolini S. Functions of natural killer cells. Nat Immunol (2008) 9(5):503-10. doi:10.1038/ni1582

9. Yoon JC, Yang CM, Song Y, Lee JM. Natural killer cells in hepatitis C: current progress. World J Gastroenterol (2016) 22(4):1449-60. doi:10.3748/ wjg.v22.i4.1449

10. Nagler A, Lanier LL, Cwirla S, Phillips JH. Comparative studies of human FcRIII-positive and negative natural killer cells. J Immunol (1989) 143(10): 3183-91.

11. Cooper MA, Fehniger TA, Turner SC, Chen KS, Ghaheri BA, Ghayur T, et al. Human natural killer cells: a unique innate immunoregulatory role for the CD56(bright) subset. Blood (2001) 97(10):3146-51. doi:10.1182/blood.V97. 10.3146

12. Jacobs R, Hintzen G, Kemper A, Beul K, Kempf S, Behrens G, et al. CD56bright cells differ in their KIR repertoire and cytotoxic features from CD56dim NK cells. Eur J Immunol (2001) 31(10):3121-7. doi:10.1002/15214141(2001010)31:10<3121::AID-IMMU3121>3.0.CO;2-4

13. Moretta L. Dissecting CD56dim human NK cells. Blood (2010) 116(19): 3689-91. doi:10.1182/blood-2010-09-303057

14. De Maria A, Bozzano F, Cantoni C, Moretta L. Revisiting human natural killer cell subset function revealed cytolytic CD56(dim)CD16+ NK cells as rapid producers of abundant IFN-gamma on activation. Proc Natl Acad Sci U S A (2011) 108(2):728-32. doi:10.1073/pnas.1012356108

15. Vivier E, Nunes JA, Vely F. Natural killer cell signaling pathways. Science (2004) 306(5701):1517-9. doi:10.1126/science.1103478
Target Lung staff who coordinated lung tissue samples. We extend our gratitude to all the volunteers who provided lung and blood samples.

\section{FUNDING}

This work was part funded by the BMA HC Roscoe Award 2013 to KS and TW. GC was funded by a 4 -year MRC PhD studentship. The authors also gratefully acknowledge the support of the Southampton AAIR charity.

\section{SUPPLEMENTARY MATERIAL}

The Supplementary Material for this article can be found online at https://www.frontiersin.org/articles/10.3389/fimmu.2018.01671/ full\#supplementary-material.

16. Mandelboim O, Lieberman N, Lev M, Paul L, Arnon TI, Bushkin Y, et al Recognition of haemagglutinins on virus-infected cells by NKp46 activates lysis by human NK cells. Nature (2001) 409(6823):1055-60. doi:10.1038/ 35059110

17. Draghi M, Pashine A, Sanjanwala B, Gendzekhadze K, Cantoni C, Cosman D, et al. NKp46 and NKG2D recognition of infected dendritic cells is necessary for NK cell activation in the human response to influenza infection. J Immunol (2007) 178(5):2688-98. doi:10.4049/jimmunol.178.5.2688

18. Achdout H, Manaster I, Mandelboim O. Influenza virus infection augments NK cell inhibition through reorganization of major histocompatibility complex class I proteins. J Virol (2008) 82(16):8030-7. doi:10.1128/JVI. 00870-08

19. He XS, Draghi M, Mahmood K, Holmes TH, Kemble GW, Dekker CL, et al. T cell-dependent production of IFN-gamma by NK cells in response to influenza A virus. J Clin Invest (2004) 114(12):1812-9. doi:10.1172/ JCI22797

20. He XS, Holmes TH, Zhang C, Mahmood K, Kemble GW, Lewis DB, et al. Cellular immune responses in children and adults receiving inactivated or live attenuated influenza vaccines. J Virol (2006) 80(23):11756-66. doi:10.1128/ JVI.01460-06

21. Long BR, Michaelsson J, Loo CP, Ballan WM, Vu BA, Hecht FM, et al. Elevated frequency of gamma interferon-producing NK cells in healthy adults vaccinated against influenza virus. Clin Vaccine Immunol (2008) 15(1):120-30. doi:10.1128/CVI.00357-07

22. Jost S, Quillay H, Reardon J, Peterson E, Simmons RP, Parry BA, et al. Changes in cytokine levels and NK cell activation associated with influenza. PLoS One (2011) 6(9):e25060. doi:10.1371/journal.pone.0025060

23. Stein-Streilein J, Guffee J. In vivo treatment of mice and hamsters with antibodies to asialo GM1 increases morbidity and mortality to pulmonary influenza infection. J Immunol (1986) 136(4):1435-41.

24. Gazit R, Gruda R, Elboim M, Arnon TI, Katz G, Achdout H, et al. Lethal influenza infection in the absence of the natural killer cell receptor gene Ncr1. Nat Immunol (2006) 7(5):517-23. doi:10.1038/ni1322

25. Nogusa S, Ritz BW, Kassim SH, Jennings SR, Gardner EM. Characterization of age-related changes in natural killer cells during primary influenza infection in mice. Mech Ageing Dev (2008) 129(4):223-30. doi:10.1016/j.mad. 2008.01.003

26. Kumar P, Thakar MS, Ouyang W, Malarkannan S. IL-22 from conventional NK cells is epithelial regenerative and inflammation protective during influenza infection. Mucosal Immunol (2013) 6(1):69-82. doi:10.1038/mi. 2012.49

27. Zhou K, Wang J, Li A, Zhao W, Wang D, Zhang W, et al. Swift and strong NK cell responses protect 129 mice against high-dose influenza virus infection. J Immunol (2016) 196(4):1842-54. doi:10.4049/jimmunol.1501486

28. Abdul-Careem MF, Mian MF, Yue G, Gillgrass A, Chenoweth MJ, Barra NG, et al. Critical role of natural killer cells in lung immunopathology during 
influenza infection in mice. J Infect Dis (2012) 206(2):167-77. doi:10.1093/ infdis/jis340

29. Zhou G, Juang SW, Kane KP. NK cells exacerbate the pathology of influenza virus infection in mice. Eur J Immunol (2013) 43(4):929-38. doi:10.1002/ eji.201242620

30. Koopman LA, Kopcow HD, Rybalov B, Boyson JE, Orange JS, Schatz F, et al. Human decidual natural killer cells are a unique NK cell subset with immunomodulatory potential. J Exp Med (2003) 198(8):1201-12. doi:10.1084/ jem. 20030305

31. Marquardt N, Beziat V, Nystrom S, Hengst J, Ivarsson MA, Kekalainen E, et al. Cutting edge: identification and characterization of human intrahepatic CD49a+ NK cells. JImmunol (2015) 194(6):2467-71. doi:10.4049/ jimmunol.1402756

32. Björkström NK, Ljunggren H-G, Michaëlsson J. Emerging insights into natural killer cells in human peripheral tissues. Nat Rev Immunol (2016) 16:310-20. doi:10.1038/nri.2016.34

33. Lugthart G, Melsen JE, Vervat C, van Ostaijen-ten Dam MM, Corver WE, Roelen DL, et al. Human lymphoid tissues harbor a distinct CD69+CXCR6+ NK cell population. J Immunol (2016) 197(1):78-84. doi:10.4049/jimmunol. 1502603

34. Montaldo E, Vacca P, Chiossone L, Croxatto D, Loiacono F, Martini S, et al. Unique Eomes(+) NK cell subsets are present in uterus and decidua during early pregnancy. Front Immunol (2016) 6:646. doi:10.3389/fimmu. 2015.00646

35. Peng H, Tian Z. Natural killer cell memory: progress and implications. Front Immunol (2017) 8:1143. doi:10.3389/fimmu.2017.01143

36. Robinson BW, Pinkston P, Crystal RG. Natural killer cells are present in the normal human lung but are functionally impotent. JClin Invest (1984) 74(3):942-50. doi:10.1172/JCI111513

37. Michel T, Poli A, Domingues O, Mauffray M, Theresine M, Brons NH, et al. Mouse lung and spleen natural killer cells have phenotypic and functional differences, in part influenced by macrophages. PLoS One (2012) 7(12): e51230. doi:10.1371/journal.pone.0051230

38. Wang J, Li F, Zheng M, Sun R, Wei H, Tian Z. Lung natural killer cells in mice: phenotype and response to respiratory infection. Immunology (2012) 137(1):37-47. doi:10.1111/j.1365-2567.2012.03607.x

39. Marquardt N, Kekäläinen E, Chen P, Kvedaraite E, Wilson JN, Ivarsson MA, et al. Human lung natural killer cells are predominantly comprised of highly differentiated hypofunctional CD69-CD56dim cells. J Allergy Clin Immunol (2017) 139(4):1321-30. doi:10.1016/j.jaci.2016.07.043

40. Li T, Wang J, Wang Y, Chen Y, Wei H, Sun R, et al. Respiratory influenza virus infection induces memory-like liver NK cells in mice. J Immunol (2017) 198(3):1242-52. doi:10.4049/jimmunol.1502186

41. Dou Y, Fu B, Sun R, Li W, Hu W, Tian Z, et al. Influenza vaccine induces intracellular immune memory of human NK cells. PLoS One (2015) 10(3): e0121258. doi:10.1371/journal.pone.0121258

42. Nicholas B, Staples KJ, Moese S, Meldrum E, Ward J, Dennison P, et al. A novel lung explant model for the ex vivo study of efficacy and mechanisms of anti-influenza drugs. J Immunol (2015) 194(12):6144-54. doi:10.4049/ jimmunol.1402283

43. Staples KJ, Nicholas B, McKendry RT, Spalluto CM, Wallington JC, Bragg CW, et al. Viral infection of human lung macrophages increases PDL1 expression via IFNbeta. PLoS One (2015) 10(3):e0121527. doi:10.1371/journal. pone. 0121527

44. McKendry RT, Spalluto CM, Burke H, Nicholas B, Cellura D, Al-Shamkhani A, et al. Dysregulation of antiviral function of CD8(+) $\mathrm{T}$ cells in the chronic obstructive pulmonary disease lung. Role of the PD-1-PD-L1 axis. Am J Respir Crit Care Med (2016) 193(6):642-51. doi:10.1164/rccm.201504-0782OC

45. Cooper GE, Pounce ZC, Wallington JC, Bastidas-Legarda LY, Nicholas B, Chidomere C, et al. Viral inhibition of bacterial phagocytosis by human macrophages: redundant role of CD36. PLoS One (2016) 11(10):e0163889. doi:10.1371/journal.pone.0163889

46. Staples KJ, Hinks TSC, Ward JA, Gunn V, Smith C, Djukanović R. Phenotypic characterization of lung macrophages in asthmatic patients: overexpression of CCL17. J Allergy Clin Immunol (2012) 130(6):1404-12.e7. doi:10.1016/j. jaci.2012.07.023

47. Bjorkstrom NK, Riese P, Heuts F, Andersson S, Fauriat C, Ivarsson MA, et al. Expression patterns of NKG2A, KIR, and CD57 define a process of CD56dim
NK-cell differentiation uncoupled from NK-cell education. Blood (2010) 116(19):3853-64. doi:10.1182/blood-2010-04-281675

48. Lopez-Verges S, Milush JM, Pandey S, York VA, Arakawa-Hoyt J, Pircher H, et al. CD57 defines a functionally distinct population of mature NK cells in the human CD56dimCD16+ NK-cell subset. Blood (2010) 116(19):3865-74. doi:10.1182/blood-2010-04-282301

49. Freud AG, Yokohama A, Becknell B, Lee MT, Mao HC, Ferketich AK, et al. Evidence for discrete stages of human natural killer cell differentiation in vivo. J Exp Med (2006) 203(4):1033-43. doi:10.1084/jem.20052507

50. Poli A, Michel T, Theresine M, Andres E, Hentges F, Zimmer J. CD56bright natural killer (NK) cells: an important NK cell subset. Immunology (2009) 126(4):458-65. doi:10.1111/j.1365-2567.2008.03027.x

51. Uhrberg M, Parham P, Wernet P. Definition of gene content for nine common group B haplotypes of the Caucasoid population: KIR haplotypes contain between seven and eleven KIR genes. Immunogenetics (2002) 54(4):221-9. doi:10.1007/s00251-002-0463-7

52. Middleton D, Gonzelez F. The extensive polymorphism of KIR genes. Immunology (2010) 129(1):8-19. doi:10.1111/j.1365-2567.2009.03208.x

53. Guma M, Budt M, Saez A, Brckalo T, Hengel H, Angulo A, et al. Expansion of CD94/NKG2C+ NK cells in response to human cytomegalovirus-infected fibroblasts. Blood (2006) 107(9):3624-31. doi:10.1182/blood-2005-09-3682

54. Schlums H, Cichocki F, Tesi B, Theorell J, Beziat V, Holmes TD, et al. Cytomegalovirus infection drives adaptive epigenetic diversification of NK cells with altered signaling and effector function. Immunity (2015) 42(3):443-56. doi:10.1016/j.immuni.2015.02.008

55. Freeman CM, Stolberg VR, Crudgington S, Martinez FJ, Han MK, Chensue SW, et al. Human CD56+ cytotoxic lung lymphocytes kill autologous lung cells in chronic obstructive pulmonary disease. PLoS One (2014) 9(7):e103840. doi:10.1371/journal.pone.0103840

56. Kim HM, Lee Y-W, Lee K-J, Kim HS, Cho SW, van Rooijen N, et al. Alveolar macrophages are indispensable for controlling influenza viruses in lungs of pigs. J Virol (2008) 82(9):4265-74. doi:10.1128/JVI.02602-07

57. Tate MD, Pickett DL, van Rooijen N, Brooks AG, Reading PC. Critical role of airway macrophages in modulating disease severity during influenza virus infection of mice. J Virol (2010) 84(15):7569-80. doi:10.1128/JVI.00291-10

58. Purnama C, Ng SL, Tetlak P, Setiagani YA, Kandasamy M, Baalasubramanian $S$, et al. Transient ablation of alveolar macrophages leads to massive pathology of influenza infection without affecting cellular adaptive immunity. Eur J Immunol (2014) 44(7):2003-12. doi:10.1002/eji.201344359

59. Nedvetzki S, Sowinski S, Eagle RA, Harris J, Vely F, Pende D, et al. Reciprocal regulation of human natural killer cells and macrophages associated with distinct immune synapses. Blood (2007) 109(9):3776-85. doi:10.1182/blood2006-10-052977

60. Bellora F, Castriconi R, Dondero A, Reggiardo G, Moretta L, Mantovani A, et al. The interaction of human natural killer cells with either unpolarized or polarized macrophages results in different functional outcomes. Proc Natl Acad Sci U S A (2010) 107(50):21659-64. doi:10.1073/pnas.1007654108

61. Spits H, Artis D, Colonna M, Diefenbach A, Di Santo JP, Eberl G, et al. Innate lymphoid cells - a proposal for uniform nomenclature. Nat Rev Immunol (2013) 13(2):145-9. doi:10.1038/nri3365

62. De Grove KC, Provoost S, Verhamme FM, Bracke KR, Joos GF, Maes T, et al. Characterization and quantification of innate lymphoid cell subsets in human lung. PLoS One (2016) 11(1):e0145961. doi:10.1371/journal.pone.0145961

63. Finch DK, Stolberg VR, Ferguson J, Alikaj H, Kady MR, Richmond BW, et al. Lung dendritic cells drive NK cytotoxicity in chronic obstructive pulmonary disease via IL-15Ralpha. Am J Respir Crit Care Med (2018). doi:10.1164/ rccm.201712-2513OC

64. Hutton AJ, Polak ME, Spalluto CM, Wallington JC, Pickard C, Staples KJ, et al. Human lung fibroblasts present bacterial antigens to autologous lung Th cells. J Immunol (2017) 198(1):110-8. doi:10.4049/jimmunol.1600602

65. Zimmer J, Andres E, Hentges F. NK cell subsets and CD107a mobilization assay. Leukemia (2005) 19(10):1849-1851; author reply 1857. doi:10.1038/sj.leu.2403906

66. Grzywacz B, Kataria N, Verneris MR. CD56dimCD16+ NK cells downregulate CD16 following target cell induced activation of matrix metalloproteinases. Leukemia (2007) 21(2):356-9. doi:10.1038/sj.leu.2404499

67. Penack O, Gentilini C, Fischer L, Asemissen AM, Scheibenbogen C, Thiel E, et al. CD56dimCD16neg cells are responsible for natural cytotoxicity against tumor targets. Leukemia (2005) 19(5):835-40. doi:10.1038/sj.leu.2403704 
68. Lutz CT, Karapetyan A, Al-Attar A, Shelton BJ, Holt KJ, Tucker JH, et al. Human NK cells proliferate and die in vivo more rapidly than T cells in healthy young and elderly adults. JImmunol (2011) 186(8):4590-8. doi:10.4049/ jimmunol.1002732

69. Romee R, Foley B, Lenvik T, Wang Y, Zhang B, Ankarlo D, et al. NK cell CD16 surface expression and function is regulated by a disintegrin and metalloprotease-17 (ADAM17). Blood (2013) 121(18):3599-608. doi:10.1182/ blood-2012-04-425397

70. Hwang I, Scott JM, Kakarla T, Duriancik DM, Choi S, Cho C, et al. Activation mechanisms of natural killer cells during influenza virus infection. PLoS One (2012) 7(12):e51858. doi:10.1371/journal.pone.0051858

71. Madera S, Rapp M, Firth MA, Beilke JN, Lanier LL, Sun JC. Type I IFN promotes NK cell expansion during viral infection by protecting NK cells against fratricide. J Exp Med (2016) 213(2):225-33. doi:10.1084/ jem.20150712

72. Ferlazzo G, Thomas D, Lin SL, Goodman K, Morandi B, Muller WA, et al. The abundant NK cells in human secondary lymphoid tissues require activation to express killer cell Ig-like receptors and become cytolytic. J Immunol (2004) 172(3):1455-62. doi:10.4049/jimmunol.172. 3.1455
73. Mahmoud AB, Tu MM, Wight A, Zein HS, Rahim MM, Lee SH, et al. Influenza virus targets class I MHC-educated NK cells for immunoevasion. PLoS Pathog (2016) 12(11):e1006021. doi:10.1371/journal.ppat.1006021

74. Motz GT, Eppert BL, Wortham BW, Amos-Kroohs RM, Flury JL, Wesselkamper SC, et al. Chronic cigarette smoke exposure primes NK cell activation in a mouse model of chronic obstructive pulmonary disease. J Immunol (2010) 184(8):4460-9. doi:10.4049/jimmunol.0903654

Conflict of Interest Statement: KS and TW have applied for a patent for the explant infection model (PCT/GB2010/050821 "Ex Vivo Modelling of Therapeutic Interventions"). They report funding from GSK Biologicals SA and AstraZeneca outside of the submitted work. GC, KO, and SK have no potential conflict of interest to declare.

Copyright (c) 2018 Cooper, Ostridge, Khakoo, Wilkinson and Staples. This is an openaccess article distributed under the terms of the Creative Commons Attribution License (CC BY). The use, distribution or reproduction in other forums is permitted, provided the original author(s) and the copyright owner(s) are credited and that the original publication in this journal is cited, in accordance with accepted academic practice. No use, distribution or reproduction is permitted which does not comply with these terms. 